\title{
Modelling basin-wide variations in Amazon forest productivity - Part 1: Model calibration, evaluation and upscaling functions for canopy photosynthesis
}

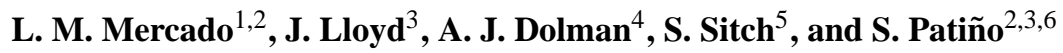 \\ ${ }^{1}$ Centre for Ecology and Hydrology, Wallingford, Oxon, OX10 8BB, UK \\ ${ }^{2}$ Max Planck Institute for Biogeochemistry, 07745 Jena, Germany \\ ${ }^{3}$ School of Geography, University of Leeds, LS2 9JT, UK \\ ${ }^{4}$ Free University of Amsterdam, $1081 \mathrm{HV}$ Amsterdam, The Netherlands \\ ${ }^{5}$ Met Office Hadley Centre, JCHMR, Wallingford, Oxon, OX10 8BB, UK \\ ${ }^{6}$ Instituto de Investigación de Recursos Biológicos Alexander von Humboldt, Diagonal 27 No. 15-09, Bogotá D.C, Colombia
}

Received: 22 December 2008 - Published in Biogeosciences Discuss.: 11 March 2009

Revised: 12 June 2009 - Accepted: 26 June 2009 - Published: 28 July 2009

\begin{abstract}
Given the importance of Amazon rainforest in the global carbon and hydrological cycles, there is a need to parameterize and validate ecosystem gas exchange and vegetation models for this region in order to adequately simulate present and future carbon and water balances. In this study, a sun and shade canopy gas exchange model is calibrated and evaluated at five rainforest sites using eddy correlation measurements of carbon and energy fluxes.

Results from the model-data evaluation suggest that with adequate parameterisation, photosynthesis models taking into account the separation of diffuse and direct irradiance and the dynamics of sunlit and shaded leaves can accurately represent photosynthesis in these forests. Also, stomatal conductance formulations that only take into account atmospheric demand fail to correctly simulate moisture and $\mathrm{CO}_{2}$ fluxes in forests with a pronounced dry season, particularly during afternoon conditions. Nevertheless, it is also the case that large uncertainties are associated not only with the eddy correlation data, but also with the estimates of ecosystem respiration required for model validation. To accurately simulate Gross Primary Productivity (GPP) and energy partitioning the most critical parameters and model processes are the quantum yield of photosynthetic uptake, the maximum carboxylation capacity of Rubisco, and simulation of stomatal conductance.
\end{abstract}

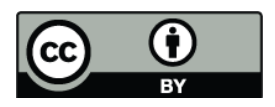

Correspondence to: L. M. Mercado (lmme@ceh.ac.uk)
Using this model-data synergy, we developed scaling functions to provide estimates of canopy photosynthetic parameters for a range of diverse forests across the Amazon region, utilising the best fitted parameter for maximum carboxylation capacity of Rubisco, and foliar nutrients ( $\mathrm{N}$ and P) for all sites.

\section{Introduction}

The Amazon forest is the largest example of tropical rain forest in the world and it is estimated to be among the most productive ecosystems in the world (Grace et al., 2001). It has received considerable attention due to its potential capacity to act as a source or sink of atmospheric carbon dioxide (Grace et al., 1995a; Lloyd and Farquhar, 1996, 2008; Phillips et al., 1998; Prentice and Lloyd, 1998; Tian et al., 1998; Chambers and Silver, 2004; Lewis et al., 2004). Results from global carbon cycle models have suggested a potential significant effect of Amazonian forests on estimates of the global carbon budget (Prentice and Lloyd, 1998; Tian et al., 1998; Cox et al., 2000). Indeed, the study of Cox et al. (2000), predicts large-scale forest dieback across Amazonia in the 21st century, with associated emissions contributing to an amplification of human-induced climate change. Such results need to be refined using calibrated models that are better constrained by data from the Amazon region. These should lead to improved present and future carbon balances predictions for Amazonia. This is of vital importance

Published by Copernicus Publications on behalf of the European Geosciences Union. 
for the accuracy of global climate-carbon cycle models and their projections of future atmospheric carbon dioxide concentration and climate.

Although land surface schemes within Global Circulation Models (GCMs) currently represent vegetation in terms of a small set of plant functional types (PFTs) (Sitch et al., 2003), progress is now being made in this respect, associated with a greater appreciation of the physiological diversity of the many different species and the wide diversity of soil types in the region (Fyllas et al., 2009). Thus although the entire Amazon rainforest is taken as one physiologically uniform entity, it is now appropriate for models of Amazon forest gas exchange to incorporate variations in plant physiological characteristics and soil properties.

The increased availability of eddy correlation flux data has been very useful for calibrating and evaluating model ability to simulate measurements and ecosystem responses to different environmental variables. Nevertheless it is important to note some limitations of the method, such as a failure to close the energy balance (Massman and Lee, 2002; Wilson et al., 2002; Baldocchi, 2003; Finnigan et al., 2003) and that the method only estimates the net ecosystem carbon exchange. This comprises two large and opposing fluxes associated with processes that often occur simultaneously: viz. photosynthesis by leaves, and whole-ecosystem respiration, i.e. the combination of plant and heterotrophic respiration. Separating the net flux into its components is nontrivial, and is usually achieved by relating respiration to the net ecosystem exchange measured during night-time. There are two drawbacks in estimating ecosystem respiration using this method: first, daytime ecosystem respiration differs from night-time due to temperature differences, especially at the canopy level. Second, and most importantly, there is a frequent failure of the system to measure night-time respiration fluxes at low wind speed conditions (Aubinet et al., 2002; Massman and Lee, 2002; Pattey et al., 2002; Saleska et al., 2003).

Carbon isotope measurements of plant tissues $\left(\delta^{13} \mathrm{C}\right)$ place a constraint on models of isotopic discrimination during photosynthesis (Aranibar et al., 2006). These measurements for $\mathrm{C}_{3}$ plants give an indication of the average intercellular $\mathrm{CO}_{2}$ concentration $\left(C_{i}\right)$ during photosynthetic periods (Farquhar et al., 1982). This metric has been used in modelling studies to constrain the stomatal conductance parameters (Aranibar et al., 2006).

Under the assumption of nitrogen $(\mathrm{N})$ limitation, leaf photosynthesis is usually modelled based on the measured linearity between photosynthetic capacity and $\mathrm{N}$ content per unit leaf area (Hirose and Werger, 1987; Evans, 1993). Leaf photosynthesis is scaled up to canopy level based on the hypothesis that $\mathrm{N}$ partitioning within canopies varies with irradiance in such a way as to maximize whole-canopy photosynthesis (Evans, 1993). This optimal approach to N partitioning is frequently used in the modelling community. However, for tropical ecosystems leaf phosphorous $(\mathrm{P})$ rather than leaf $\mathrm{N}$ may be the key nutrient limiting productivity of lowland rainforests, where soils are highly weathered, phosphorous availability is low and nitrogen is relatively abundant (Vitousek and Sanford, 1986). Aside from the importance of many sugar-phosphates in photosynthesis and respiration, phosphorous plays an essential role in energy metabolism because of its presence in important molecules that store energy which are essential to the Calvin cycle. Therefore, deficiencies in phosphorus can limit the rates of RuBP regeneration ( $\mathrm{RuBP}$ is the $\mathrm{CO}_{2}$ acceptor molecule in the Calvin cycle) and consequently carbon assimilation (Campbell and Sage, 2006). It is likely the low $P$ concentrations in tropical forest leaves may constrain photosynthetic rate, at least for some tropical forests (Lloyd et al., 2001). Lloyd et al. (2009) have also shown that the "optimal" gradient of $\mathrm{N}$ and $\mathrm{P}$ within plant canopies is actually less steep than has often been considered the case, especially when overall nutrient concentrations are low.

The motivation behind this study is thus to refine ecosystem gas exchange models in order to better represent the gross carbon uptake of forests in the Amazon Basin, utilising available eddy correlation data and other field observations, for model calibration and evaluation. Then, we can derive upscaling relationships of canopy photosynthesis appropriate for basin-wide simulations. We first assess model performance of simulated carbon uptake and energy partition at five rainforest sites in the Amazon basin using eddy correlation flux data and identify the main limitations of such a model-data evaluation exercise. We take the sun/shade model for photosynthesis (de Pury and Farquhar, 1997) coupled to a stomatal conductance model (Cowan and Farquhar, 1977), previously calibrated at one rainforest site, as described in Mercado et al. (2006). This coupled model is applied at 5 eddy correlation sites across Amazonia. It is calibrated and then evaluated using fluxes of carbon and energy derived from eddy correlation data, and measurements of foliar carbon isotope fractionation (Lloyd et al., 2009; Fyllas et al., 2009). Then, we derive a canopy scaling function to scale GPP to the basin level. Here we relate canopy maximum carboxylation capacity of Rubisco activity $\left(V_{\max }\right)$ at each site to foliar N. Additionally, given the possibility of phosphorus deficiency in tropical leaves being an important constraint on photosynthesis (Lloyd et al., 2001), relationships between $V_{\max }$ and foliar phosphorus are also explored.

\section{Methods}

\subsection{Data}

\subsubsection{Tower sites}

Eddy correlation measurements made above five primary rainforest sites in the Brazilian Amazon (averaged over hourly time steps) with associated meteorological variables, 
Table 1. Information about eddy correlation data used from five sites in the Brazilian Amazon.

\begin{tabular}{|c|c|c|c|c|c|}
\hline & Man C14 & Man K34 & Jaru & Tapajos & Caxiuana \\
\hline Period used & 10/1995-07/1996 & $\begin{array}{l}10 / 1999-05 / 2000 \\
10 / 2000-12 / 2000\end{array}$ & All 1999 & All 2002 & 1999 \\
\hline Storage Flux & modelled & measured & $\begin{array}{l}1999 \text { measured } \\
2000 \text { modelled }\end{array}$ & measured & $\begin{array}{l}\text { Measured few small } \\
\text { gaps modelled }\end{array}$ \\
\hline $\begin{array}{l}\text { Energy balance } \\
\text { closure }\end{array}$ & $94 \%$ & $70 \%$ & $70 \%$ & $\begin{array}{l}87 \% \text { including heat } \\
\text { storage from ground } \\
\text { and vegetation }\end{array}$ & $70 \%$ \\
\hline $\begin{array}{l}\text { Correction applied } \\
\text { to data used }\end{array}$ & $\begin{array}{l}\text { Low frequency } \\
\text { contributions }\end{array}$ & $\begin{array}{l}\text { no corrections } \\
\text { applied to data set used } \\
\text { at the time simulations } \\
\text { were performed }\end{array}$ & $\begin{array}{l}\text { no corrections } \\
\text { applied to data set used } \\
\text { at the time simulations } \\
\text { were performed }\end{array}$ & Night time $\mathrm{u}^{*}$ & $\begin{array}{l}\text { Low frequency } \\
\text { contributions }\end{array}$ \\
\hline
\end{tabular}

Table 2. General characteristics of five rainforest sites in the Brazilian Amazon.

\begin{tabular}{|c|c|c|c|c|c|}
\hline & Man C14 & Man K34 & Jaru & Tapajos km 67 & Caxiuana \\
\hline Geographical coordinates & $\begin{array}{l}2^{\circ} 35^{\prime} 21.08^{\prime \prime} \mathrm{S} \\
60^{\circ} 06^{\prime} 53.63^{\prime \prime} \mathrm{W}\end{array}$ & $\begin{array}{l}2^{\circ} 36^{\prime} 32.67^{\prime \prime} \mathrm{S} \\
60^{\circ} 12^{\prime} 33.48^{\prime \prime} \mathrm{W}\end{array}$ & $\begin{array}{l}10^{\circ} 4.706^{\prime} \mathrm{S} \\
61^{\circ} 56.03^{\prime} \mathrm{W}\end{array}$ & $03^{\circ} 03^{\prime} \mathrm{S} 54^{\circ} 56^{\prime} \mathrm{W}$ & $01.42^{\circ} \mathrm{S} 51.32^{\circ} \mathrm{W}$ \\
\hline Location & $\begin{array}{l}\text { Cuieiras Reserve } \\
\text { Previously known } \\
\text { as ZF2 Manaus, } \\
\text { Amazonas }\end{array}$ & $\begin{array}{l}10 \mathrm{~km} \text { away from the } \\
\text { C14 site Manaus, } \\
\text { Amazonas }\end{array}$ & $\begin{array}{l}\text { Reserva Jaru } \\
100 \text { km north of } \\
\text { Ji-Parana, Rondonia }\end{array}$ & $\begin{array}{l}\text { Tapajos National forest } \\
70 \mathrm{~km} \text { south of } \\
\text { Santarem, Para }\end{array}$ & $\begin{array}{l}1 \mathrm{~km} \text { north of field station } \\
\text { floresta } \\
\text { Nacional de Caxiuana, Para }\end{array}$ \\
\hline Tower height (m) & 41.5 & 52 & 62 & 65 & 51.5 \\
\hline Mean elevation (m) & $100-150$ & $100 \pm 50$ & $150-200$ & 90 & 15 \\
\hline Forest type & Terra firme & Terra firme & Terra firme & Terra firme & Terra firme \\
\hline Canopy height (m) & $30-35$ & $30-35$ & 35 up to 45 & 40 emergent up to 55 & $\sim 35$ \\
\hline $\operatorname{LAI}\left({\left.\mathrm{m} 2 \mathrm{~m}^{-2}\right)}\right.$ & 5.6 & 4.4 & 4 & 6.7 & 5.4 \\
\hline Type of soil & $\begin{array}{l}\text { Geric carric Ferrasol } \\
\text { (Alumic Hyperdystric, } \\
\text { Clayic) }^{\mathrm{a}}\end{array}$ & $\begin{array}{l}\text { Geric Ferrasol } \\
\text { (Alumirc Hyperdystric, } \\
\text { Clayic) }^{\mathrm{a}}\end{array}$ & Red-yellow acrisol1 ${ }^{\mathrm{b}}$ & $\begin{array}{l}\text { Oxisol Geric Ferrasol } \\
\text { (Alumic, Hyperdystric, } \\
\text { Clayic, Xanthick) }^{\mathrm{a}}\end{array}$ & $\begin{array}{l}\text { Geric, Acric, Ferrasol } \\
\text { (Alumic Hyperdystric, } \\
\text { Clayic) }^{\mathrm{a}}\end{array}$ \\
\hline Mean temperature $\left({ }^{\circ} \mathrm{C}\right)$ & 26.7 & 26.7 & $25-27$ & $\begin{array}{l}\max [24-32] \& \\
\min [20-25]\end{array}$ & 27 \\
\hline $\begin{array}{l}\text { Mean precipitation } \\
\left(\mathrm{mm}_{\text {year }}{ }^{-1}\right)\end{array}$ & $1900-2300$ & $1900-2300$ & 1900 & 1920 & 2300 \\
\hline $\begin{array}{l}\text { Dry season length } \\
\text { (months with rainfall } \\
<100 \mathrm{~mm} \text { ) }\end{array}$ & Jun-Sep & Jun-Sep & May/Jun-Sep & Jun-Dec & Jun-Aug \\
\hline $\begin{array}{l}\text { Mean aboveground } \\
\text { biomass (Tonne ha }{ }^{-1} \text { ) }\end{array}$ & $300-350^{\mathrm{c}}$ & $300-350^{\mathrm{c}}$ & $220^{\mathrm{d}}$ & $349.1^{\mathrm{c}}$ & $371.7^{\mathrm{c}}$ \\
\hline $\begin{array}{l}\text { Reference to site and } \\
\text { eddy correlation data }\end{array}$ & $\begin{array}{l}\text { Malhi et al. (1998); } \\
\text { Malhi et al. (2002) }\end{array}$ & $\begin{array}{l}\text { Araújo et al. (2002); } \\
\text { Chambers et al. (2004) }\end{array}$ & $\begin{array}{l}\text { von Randow } \\
\text { et al. (2004) }\end{array}$ & $\begin{array}{l}\text { Hutyra et al. (2008); } \\
\text { Saleska et al. (2003), } \\
\text { From a neighbouring site } \\
\text { (km 83): Goulden et al. } \\
\text { (2004); Miller et al. } \\
\text { (2004); Da Rocha et al. } \\
\text { (2004) }\end{array}$ & $\begin{array}{l}\text { Carswell et al. (2002); } \\
\text { Iwata et al. (2005) }\end{array}$ \\
\hline
\end{tabular}

${ }^{\mathrm{a}}$ Quesada et al. (2009); ${ }^{\mathrm{b}}$ von Randow et al. (2004); ${ }^{\mathrm{c}}$ Baker et al. (2004); ${ }^{\mathrm{d}}$ Meir et al. (2001)

were used to calibrate and evaluate the model used in this study. A summary of data used and site characteristics is given in Tables 1 and 2, respectively, and site locations are shown in Fig. 1. Information on instruments used for measurements and methods for flux calculations at each site can be found in the original references for these measurements as given in Table 2.

\subsubsection{Meteorology}

The meteorological data used for model input comes from automatic weather stations located at the top of the towers. Global solar radiation, wind speed and air temperature were available at all towers. To determine atmospheric water vapour content, methodologies differed between sites - 


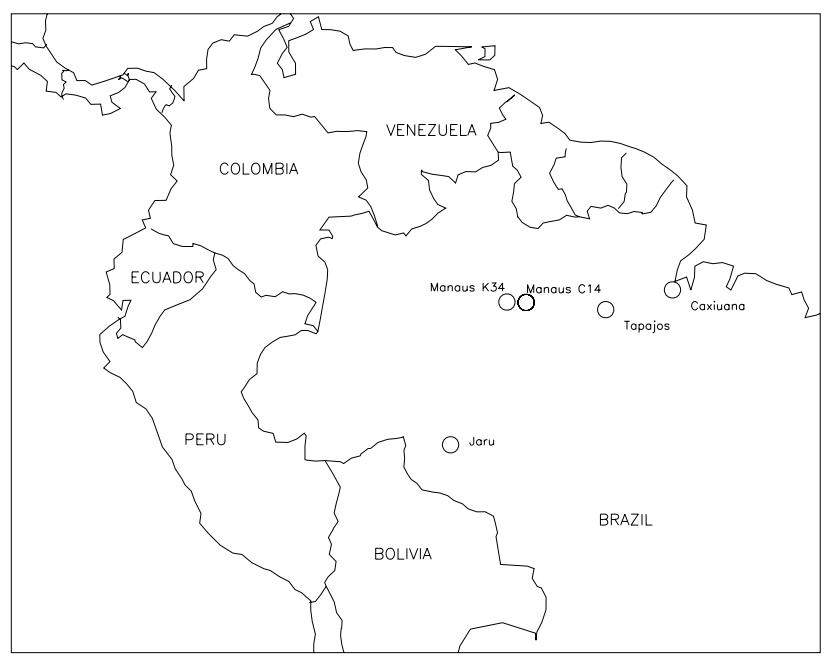

Fig. 1. Locations of rainforest sites with eddy correlation systems used in this study.

values are derived from wet bulb temperatures at Manaus C14 and Caxiuana, from dew point temperatures at Tapajos and from relative humidity measurements at Jaru and Man K34.

\subsubsection{Carbon fluxes}

Fluxes of carbon dioxide correspond to net ecosystem exchange rates $\left(N_{E}\right)$. In order to determine the net canopy assimilation rate (i.e. total photosynthesis minus daytime canopy leaf respiration $\left.R_{C}\right), G_{P}$ or gross canopy assimilation rate (i.e. total photosynthesis, which includes daytime leaf respiration) $\left(G_{P *}\right)$, it is necessary to consider the nonleaf ecosystem respiration rate $R_{E^{*}}$ or the total ecosystem respiration rate $R_{E}$, respectively, and carbon dioxide accumulated inside the canopy:

$G_{P}=-N_{E}+R_{E^{*}}$

$G_{P^{*}}=G_{P}+R_{C}=-N_{E}+R_{E}$

$N_{E}=F_{C}+\int_{0}^{h_{t}} \frac{\partial C_{a}}{\partial t} d z$

where $F_{c}$ is the flux of $\mathrm{CO}_{2}$ measured by eddy correlation $\left(\mu \mathrm{mol} \mathrm{m} \mathrm{m}^{2} \mathrm{~s}^{-1}\right.$ ) and the integrand, often referred to as "the change in canopy storage flux" $\left(\mu \mathrm{mol} \mathrm{m} \mathrm{m}^{2}\right)$, represents the rate of change in the $\mathrm{CO}_{2}$ concentration $\left(C_{a}\right)$ within the canopy between the forest floor and the eddy correlation measurement height, $h_{t}$. Canopy $\mathrm{CO}_{2}$ storage flux $\left(S_{T}\right)$ is estimated from measurements of within canopy $\mathrm{CO}_{2}$ concentrations and it is usually measured along with eddy correlation flux data.

Of the five sites, the canopy storage flux was determined from measurements at Manaus K34, Tapajos, Jaru and Caxiuana. Data from Manaus C14 only includes storage mea- surements for the period October-November 1995. Lacking measurements at Manaus $\mathrm{C} 14$ for the remaining period of study and at Jaru, simulated storage fluxes (provided by collaborators) were used.

To calculate photosynthesis from measured eddy correlation $N_{E}$, it was necessary to use either $G_{P}$ or $G_{P^{*}}$ depending upon the ecosystem respiration available at each individual site. At sites where it was possible to estimate the separate contributions to ecosystem respiration, i.e. from stems and branches, soil and coarse litter (Man K34, Jaru and Man C14), the net assimilation rate, $G_{P}$, was used. This term accounts for the balance of the parallel processes of photosynthesis and leaf respiration. At Man K34, Jaru and Man C14 the "observed" $G_{P}$ was calculated as:

$G_{P}=-N_{E}+R_{E^{*}}=-N_{E}+R_{S}+R_{W}+R_{C S}$

$R_{E_{-} N L}$ is the sum of all respiratory contributions from soil (autotrophic and heterotrophic on a ground area basis), coarse litter, stems and branches. $R_{W}$ represents the respiration contribution from stems and branches, $R_{S}$ from soil (which includes root and fine litter decomposition at the soil surface) and $R_{C S}$ accounts for coarse litter respiration. At sites where ecosystem respiration was given as a single flux (Caxiuana and Tapajos), Gross photosynthesis, $G_{P^{*}}$, is used. At Tapajos and Caxiuana, total ecosystem respiration was available and $G_{P^{*}}$ was calculated as:

$G_{P^{*}}=-N_{E}+R_{E}$

where $R_{E}$ is defined as $R_{E^{*}}$ plus respiratory contributions from daytime leaf canopy respiration.

To derive $G_{P}$ or $G_{P^{*}}$ at the five tower sites, different methodologies for estimating ecosystem respiration had to be used, these again dependent upon the techniques employed by the original investigators.

Ecosystem respiration for both Manaus sites, and Jaru, was calculated using measurements from its single components (Eq. 4) and for Tapajos and Caxiuana, ecosystem respiration was derived from night time measurements of $N_{E}$. A summary of how ecosystem respiration was calculated for each site is included in Table 3.

\subsubsection{Foliar carbon isotopes, $N$ and $P$ content and leaf area index}

Measurements of foliar carbon isotopic composition as described in Lloyd et al. (2009) and Fyllas et al. (2009) were used to test model predictions of $C_{i}$ with the exception of the Jaru site where we take data from the study of Ometto et al. (2006).

Foliar N, P (on a dry weight (DW) basis ) and leaf mass per unit area for leaves taken from the top of the canopy are as in Fyllas et al. (2009) with nitrogen and phosphorus data from Jaru kindly provided by Martinelli and Nardoto (unpublished data). 
Table 3. Calculation of ecosystem respiration for the different sites. All respiration terms are in $\mu \mathrm{mol} \mathrm{m}^{-2} \mathrm{~s}^{-1}$ (ground area basis). The range of $R_{E}$ represents seasonal variation.

\begin{tabular}{|c|c|c|c|c|}
\hline Site & \multicolumn{2}{|c|}{ Method of calculation } & Source & $R_{E}$ \\
\hline \multirow[t]{5}{*}{ Man C14 } & \multicolumn{4}{|c|}{ Sum of individual components of $R_{E}$} \\
\hline & $R_{S}$ at soil $T$ & $\min -\max [2.1-4.10]$ & Chambers et al. (2004) & $\min -\max$ \\
\hline & $R_{C S}\left(\right.$ at $\left.25^{\circ} \mathrm{C}\right)$ & 0.5 & Chambers et al. (2000) & {$[7.2-9.2]$} \\
\hline & $R_{w}\left(\right.$ at $\left.25^{\circ} \mathrm{C}\right)$ & 1.1 & Chambers et al. (2004) & \\
\hline & $R_{C, 25}$ & 3.5 & modelled & \\
\hline \multirow[t]{5}{*}{ Man K34 } & \multicolumn{4}{|c|}{ Sum of individual components of $R_{E}$} \\
\hline & $R_{S}$ at soil $T$ & $\min -\max [2.1-4.10]$ & Chambers et al. (2004) & $\min -\max$ \\
\hline & $R_{C S}\left(\right.$ at $\left.25^{\circ} \mathrm{C}\right)$ & 0.5 & Chambers et al. (2000) & {$[6.2-8.2]$} \\
\hline & $R_{w}\left(\right.$ at $\left.25^{\circ} \mathrm{C}\right)$ & 1.1 & Chambers et al. (2004) & \\
\hline & $R_{C, 25}$ & 2.5 & modelled & \\
\hline \multirow[t]{5}{*}{ Jaru } & \multicolumn{3}{|c|}{ Sum of individual components of $R_{E}$} & avg 9.3 \\
\hline & $R_{S}($ at soil $T)$ & 5.22 & Meir et al. (1996) & \\
\hline & $R_{C S}\left(\right.$ at $\left.25^{\circ} \mathrm{C}\right)$ & 0.5 & Chambers et al. (2000) & \\
\hline & $R_{w}\left(\right.$ at $\left.25^{\circ} \mathrm{C}\right)$ & 0.75 & Meir and Grace (2002) & \\
\hline & $R_{C, 25}$ & 2.66 & modelled & \\
\hline Tapajos & \multicolumn{2}{|c|}{$\begin{array}{l}\text { Inferred from night time fluxes by filtering out } \\
\text { data below particular } u * \text { thresholds. Hourly } \\
\text { values are calculated as the average of valid } \\
\text { nighttime } N_{E} \text { within a centered } 5 \text {-day wide } \\
\text { window, assuming at least } 24 \text { valid hours of } \\
\text { nighttime } N_{E} \text { were available. }\end{array}$} & $\begin{array}{l}\text { Restrepo-Coupe (2009) } \\
\text { Hutyra et al. (2008) }\end{array}$ & $\begin{array}{l}\min -\max \\
{[9-10.6]}\end{array}$ \\
\hline \multirow[t]{3}{*}{ Caxiuana } & \multicolumn{2}{|c|}{$\begin{array}{l}\text { Inferred from night time fluxes by filtering } \\
\text { out data below particular } u * \text { thresholds, and } \\
\text { applying the Michaelis Menten equation with } \\
\text { a fixed } Q_{10} \text { of } 2 \text { to soil temperature data to } \\
\text { estimate daytime respiration rates }\end{array}$} & $\begin{array}{l}\text { Iwata et al. (2005) } \\
\text { modelled }\end{array}$ & avg 8.6 \\
\hline & $R_{E}\left(\right.$ at $\left.25^{\circ} \mathrm{C}\right)$ & 8.6 & & \\
\hline & $R_{C, 25}$ & 2.7 & & \\
\hline
\end{tabular}

Leaf area index (LAI) in $\mathrm{m}^{2}$ of leaves per $\mathrm{m}^{2}$ of ground was derived from hemispherical photographs using the method of Keeling and Philips (2007) taken at 4 of the 5 sites during the end of the rainy season (Patiño, unpublished data). LAI at the remaining site, Jaru was taken from the study of Meir et al. (2000).

\subsection{Model description}

\subsubsection{Sun and shade model}

The canopy gas exchange sun and shade model used in this study (de Pury and Farquhar, 1997) simulates canopy photosynthesis and energy balance by dividing the canopy into a sunlit and shaded component. This division of sunlit and shaded foliage changes with both the portion of the incoming irradiance that is diffuse, as well as the solar elevation angle, and therefore canopy photosynthetic capacity of the sunlit and shaded portions is dynamic. Sunlit leaves are modelled to receive direct and diffuse radiation while shaded leaves receive only diffuse radiation. Details about the model and equations for canopy photosynthesis are included in Appendix A.

\subsubsection{Radiation absorption and energy balance}

Using formulations developed by Goudriaan (1977) as presented in Wang and Leuning (1998) and de Pury and Farquhar (1997), absorption of Photosynthetically Active Radiation (PAR) and near infrared radiation (NIR) was estimated for the sun/shade model. The net energy available to the sunlit and shaded leaf was calculated as the sum of net absorbed PAR, net absorbed NIR and net absorbed long wave by each leaf.

Since leaf temperature is needed to calculate long wave radiation, net isothermal radiation is calculated for the sun and shaded leaves, which are partitioned between the latent and sensible heat fluxes following the isothermal form of the Penman-Monteith equation (Jones, 1992), assuming ground evaporation and soil heat flux to be negligible. This 
Table 4. Leaf $P$ and Leaf $N$ in area and dry weight and SLA (Fyllas et al., 2009).

\begin{tabular}{llllll}
\hline Site & $\begin{array}{l}\text { Leaf P } \\
\left(\mathrm{mg} \mathrm{g}^{-1}\right)\end{array}$ & $\begin{array}{l}\text { Leaf P } \\
\left(\mathrm{g} \mathrm{m}^{-2}\right)\end{array}$ & $\begin{array}{l}\text { Leaf N } \\
\left(\mathrm{mg} \mathrm{g}^{-1}\right)\end{array}$ & $\begin{array}{l}\text { Leaf } \mathrm{N} \\
\left(\mathrm{g} \mathrm{m}^{-2}\right)\end{array}$ & $\begin{array}{l}\text { SLA } \\
\left(\mathrm{cm}^{2} \mathrm{~g}^{-1}\right)\end{array}$ \\
\hline Manaus C14 & 0.69 & 0.07 & 19.93 & 1.98 & 102.87 \\
Manaus K34 & 0.64 & 0.06 & 23.10 & 2.36 & 96.82 \\
Jaru & $0.89^{\mathrm{a}}$ & 0.084 & $27.37^{\mathrm{a}}$ & 2.6 & $105.2^{\mathrm{b}}$ \\
Caxiuana & 0.60 & 0.05 & 19.83 & 1.75 & 111.17 \\
Tapajos & 0.76 & 0.07 & 23.48 & 2.16 & 103.06 \\
\hline
\end{tabular}

a Martinelli and Nardoto (unpublished data)

b Meir et al. (2001)

assumption is based on the observation that typically only $1 \%$ of the radiation received at the top of the canopy reaches the forest floor (Shuttleworth, 1989). For example, soil heat fluxes represent only $2 \%$ of the daytime net radiation at Tapajos (da Rocha et al., 2004). Since energy stored in biomass and in the canopy air and chemical energy used for $\mathrm{CO}_{2}$ exchange are small in quantity, these terms were also neglected.

\subsubsection{Leaf biochemistry and stomatal conductance}

The leaf level photosynthesis model used here includes the biochemistry of $\mathrm{C}_{3}$ photosynthesis from Farquhar and von Caemmerer (1982) (Eqs. A3 to A6) and stomatal conductance is calculated with the equation from Cowan and Farquhar (1977), called the "Lambda" model (Eq. A7). Description of both models is included in Appendix A.

\subsubsection{Isotopic composition of leaves $\delta^{13} \mathrm{C}$}

Isotopic composition of leaves $\delta^{13} \mathrm{C}(\% \circ)$ was calculated for the canopy following Farquhar et al. (1982) as:

$\delta^{13} \mathrm{C}=\delta_{a t m}-a-(b-a) C_{i} / C_{a}$

where $a$ corresponds to the maximum fractionation due to diffusion of $\mathrm{CO}_{2}$ in air (4.4\%o) and $b$ is the maximum fractionation in the carboxylation reaction $(30 \%$ ) (Farquhar et al., 1982). $\delta_{\text {atm }}$ is $\delta^{13} \mathrm{C}$ of the air, taken as $-8.0(\%)$, the late twentieth century mean atmospheric background value (Ehleringer et al., 1987). The ratio $C_{i} / C_{a}$ corresponds to simulated daytime hourly values from the whole canopy. The simulated average integral of photosynthetic discrimination during the different seasons analyzed $\left(\bar{\delta}^{13} \mathrm{C}\right)$ is calculated with Eq. (6) using the photosynthetic flux weighted average $\left(C_{i} / C_{a}\right)$ :

$\bar{\delta}^{13} \mathrm{C}=-12.4-25.6 \frac{\sum_{i=1}^{n} G_{P i} *\left(C_{i} / C_{a}\right)}{\sum_{i=1}^{n} G_{P i}}$

Equation 6 does not include re-fixation of soil and plant respired $\mathrm{CO}_{2}$. However, measured values of $\delta^{13} \mathrm{C}$ are from top of the canopy leaves and as shown by Lloyd et al. (1996), recycling at this level in the canopy is minimal $(<5 \%)$.

\subsection{Model parameterisation}

Canopy level maximum carboxylation activity of Rubisco $\left(V_{\max }\right)$ was estimated using Eqs. (A1) and (A2). This assumes an exponential decrease in $V_{\max }$ with height (or more precisely with cumulative leaf area) as was observed for the profile of $V_{\max }$ derived from gas exchange measurements at the Manaus C14 site (Carswell et al., 2000) and parameterised in Mercado et al. (2006) for the sun and shade model for the Manaus C14 site. From the Mercado et al. (2006) parameterisation, $V_{\max }$ for the top and bottom $50 \%$ of canopy leaves averages $65 \%$ and $35 \%$ of the $V_{\max }$ of the uppermost leaves, respectively. Having defined this distribution of $V_{\max }$ with cumulative leaf area, total canopy $V_{\max }$ was then calculated at each site as the integral of leaf level $V_{\max }$ over cumulative leaf area index, as described in Eq. (A1). Lloyd et al. (2009) discuss gradients in nutrients within Amazon forests in general and conclude that for trees growing on such relatively infertile soils, such shallow within canopy gradients should, indeed, exist.

Canopy level respiration (expressed on a ground area basis) was simulated for all sites using the parameterisation for the sun and shade model from Mercado et al. (2006) as derived from Carswell et al. (2000), and was assumed to decrease exponentially with cumulative leaf area index. Respiration at the top of the canopy was taken as a constant fraction of $V_{\max }$ from top leaves (i.e. $0.022 \times V_{\max }$ ) for all sites (de Pury and Farquhar, 1997). Total canopy respiration $R_{C}$ was subsequently calculated using the same nitrogen allocation coefficient $\left(k_{n}\right)$ obtained for the exponential regression of $V_{\max }$ against cumulative leaf area index (Eq. A2), with a temperature dependence of canopy respiration given by Lloyd and Taylor (1994).

The model was calibrated using a simplex procedure to minimize the error sum of squares of the modelled photosynthesis minus the sum of net ecosystem exchange as measured by eddy correlation plus the estimated ecosystem respiration (Table 3) from a selected subset of data from each site (Nelder and Mead, 1965). Criteria of selection followed the same conditions as in Lloyd et al. (1995) and in Grace et al. (1995b). To avoid the $\mathrm{CO}_{2}$ flush or so-called morning peak, data before 09:00 was not used for model parameterisation. Storage flux values larger than $10 \mu \mathrm{mol} \mathrm{m}^{-2} \mathrm{~s}^{-1}$ and smaller than $-10 \mu \mathrm{mol} \mathrm{m} \mathrm{m}^{-2} \mathrm{~s}^{-1}$ were also neglected as were data points collected during and after rainfall. Measurements where radiation fluctuated as a result of a moving cloud (i.e. abrupt changes in solar radiation from hour to hour) were also filtered together with aerodynamic conductances lower than $0.1 \mu \mathrm{mol} \mathrm{m} \mathrm{m}^{-2} \mathrm{~s}^{-1}$.

The following parameters (from Eqs. A3, A5 and A6) were estimated from the fitting procedure: top of the canopy $V_{\max }$, the ratio $J_{\max } / V_{\max }$ and the canopy level quantum yield $(\Phi)$. We decided to fit quantum yield to the observations because a comparison from the light response curves of $N_{E}$ derived from eddy correlation measurements for the 
various sites (Fig. B1), indicates variations in slope of the linear part of the curves at the different sites. The remaining parameters for the sun/shade model, viz. the curvature factor of the light response curve, $\theta$ (Eq. A5), and the temperature sensitivity parameters of the electron transport rate (Eq. A8 $S_{J}$ and $H_{J}$ ) and Rubisco (Eq. A7) and leaf respiration temperature sensitivities (Eq. A10) were taken from Mercado et al. (2006) (i.e. $\theta$ and $H_{J}$ were taken as parameterised in the study of Carswell et al. (2000) at the leaf level and $S_{J}$ was taken as fitted for the sun/shade model in Mercado et al., 2006). The model was calibrated using eddy correlation data from end of the dry season for all sites. The parameterization for Manaus C14 was taken from Mercado et al. (2006).

Leaf reflectance and transmittance were assumed identical at all sites. Values were taken from the study of Poorter et al. (1995) where measurements were made along a vertical gradient in canopies in a tropical rainforest in Costa Rica.

As in Katul et al. (2000) and Aranibar et al. (2006), we use foliar carbon isotopes measurements from the different sites to help constrain the parameterisation of lambda $(\lambda)$ model of stomatal conductance (Eq. A11). Initial values of $\lambda$ were calculated using the Farquhar and Lloyd (1994) version of the model that allows $\lambda$ to be estimated from $\overline{C_{i} / C_{a}}$, the derived from the $\delta^{13} \mathrm{C}$ measurements and the long-term vapour pressure deficit $(\bar{D})$ :

$\lambda \approx \frac{1.6 \bar{D}\left(C_{a}-T^{*}\right)}{C_{c}^{2}\left[1-\frac{\bar{C}_{i}}{C_{a}}\right]^{2}}$

Subsequently, following Aranibar et al. (2006), values of $\lambda$ that produced similar simulated discrimination as foliar isotope ratios measured at the different sites were chosen.

\subsection{Model evaluation}

Simulated net carbon uptake and energy partition were evaluated using eddy correlation data for all sites. Because eddy correlation measurements above forest ecosystems often fail energy balance closure tests (Massman and Lee, 2002; Wilson et al., 2002; Baldocchi, 2003; Finnigan et al., 2003), it is more practical to test model performance of energy partition using the evaporative fraction (defined as the ratio between the latent heat flux and the sum of the latent and sensible heat fluxes). There is considerable variability in the hourly calculated evaporative fraction, therefore model performance is evaluated using the mean diurnal cycles of measured and simulated evaporative fraction. In addition, simulated $\delta^{13} \mathrm{C}$ values are compared to measurements of foliar isotopic fractionation as described above. Having an accurate simulated $\delta^{13} \mathrm{C}$ helps to substantiate the results for simulated photosynthetic uptake and at the same time $\delta^{13} \mathrm{C}$ fixes the range within which $\lambda$ in Eq. (A11) can vary. By increasing or decreasing $\lambda$, the partition of energy into sensible and latent heat fluxes is changed and the model can easily fit the measured energy balance, but at the same time the lambda parameter affects the photosynthetic rate through $C_{i} / C_{a}$ and thus the simulated $\delta^{13} \mathrm{C}$. Therefore a realistically simulated $\delta^{13} \mathrm{C}$ is a valuable diagnostic for testing the validity of $\lambda$, applied in a fully linked carbon/water/energy exchange model as used here.

Simulations of carbon uptake are compared with the observations using RMSE and regression coefficient $\left(R^{2}\right)$ and slope of the linear regression line of observed and simulated data pairs. Model performance is also evaluated by comparing simulated light response of photosynthesis, diurnal cycle of evaporative fraction and canopy $\delta^{13} \mathrm{C}$ with observations.

\section{Results}

\subsection{Data-model calibration}

Best fitting values for top of the canopy $V_{\max }$, ratio of $J_{\max } / V_{\max }$ and canopy level quantum yield, and non fitted parameters used for all simulations are presented in Table 5.

\subsection{Model performance: carbon uptake and energy partition}

Statistics of model performance for carbon uptake are included in Table 6 for all sites and seasons studied. The mean light response and diurnal cycles of hourly observations and simulations of $G_{P}$ (for both Manaus sites and Jaru) and $G_{P^{*}}$ for Caxiuana and Tapajos are presented in Figs. 2 and 3, respectively. Mean diurnal cycle of observed and simulated evaporative fraction is shown in Fig. 4 and comparison of observed and simulated $\delta^{13} \mathrm{C}$ is shown in Table 7. Results for each study site are discussed separately.

\subsubsection{Manaus C14}

The sun/shade model simulates reasonably well the three seasons tested within the error bars of the observations at this site (see Table 6 for statistics). However, $G_{P}$ estimated from eddy correlation measurements during the end of dry season of 1995 and the dry season of 1996 is overestimated by the model by $8 \%$ and $10 \%$, respectively. Such overestimation seems to occur mainly during the morning during both seasons (Fig. 3). In 1995 this occurs during high radiation values (PAR higher than $1000 \mu \mathrm{mol} \mathrm{m}^{-2} \mathrm{~s}^{-1}$ ) and in 1996 at all radiation levels (Fig. 2, top row). This is associated with the storage fluxes used for calculation of $N_{E}$ (Eq. 3). For this site, the storage fluxes used were model output. Comparison of simulated storage fluxes against observations (for the available period) show a tendency to under predict the measurements in the morning, implying low estimates of measured $N_{E}$, respectively (Fig. B2). This may be one reason for the model to show a tendency to overestimate morning net carbon uptake fluxes.

Simulated energy partition (Fig. 4) shows good agreement with observations at all studied seasons for this site. 

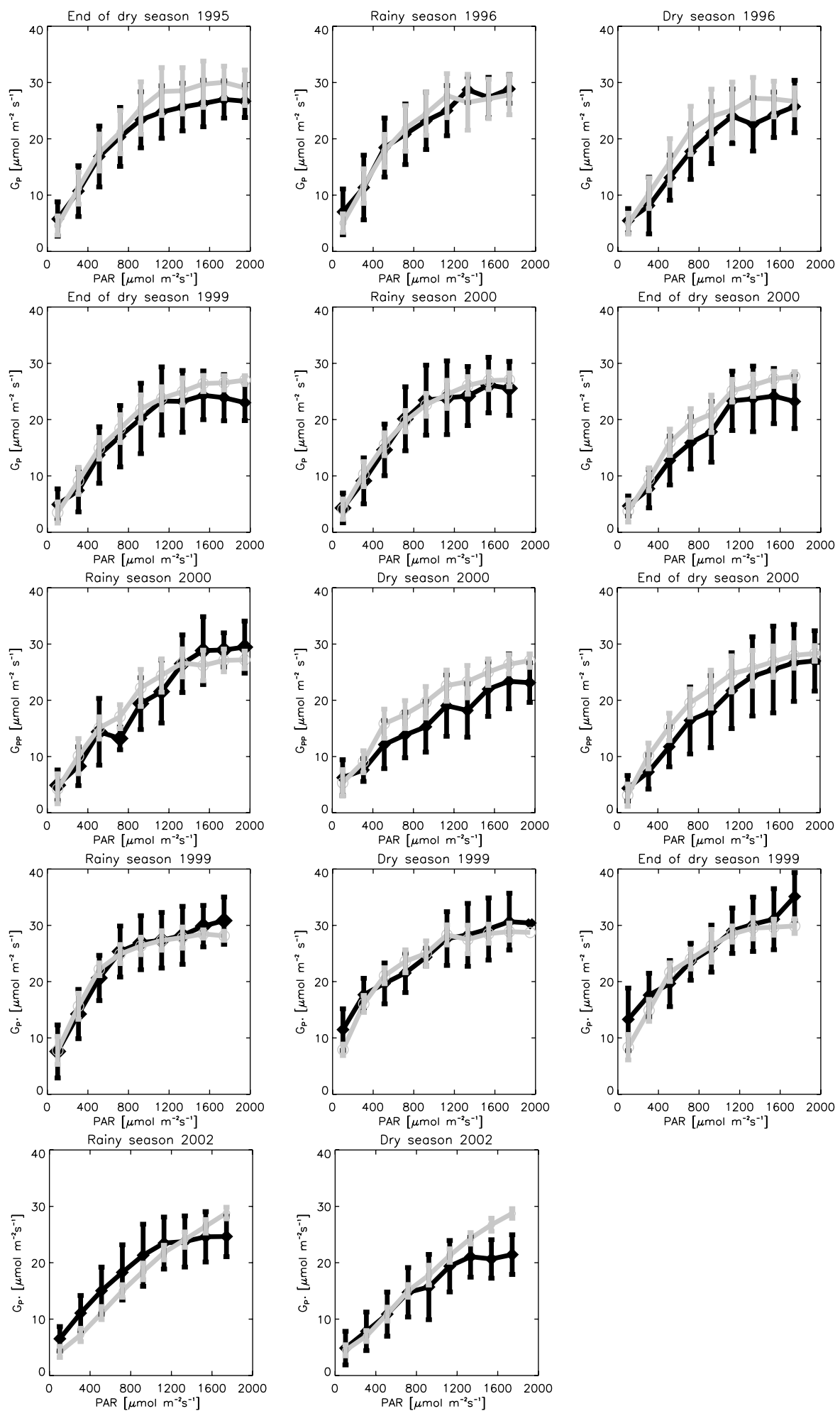

Fig. 2. Light response of observed (black) and simulated (grey) values of $G_{P}$ during the seasons tested. 

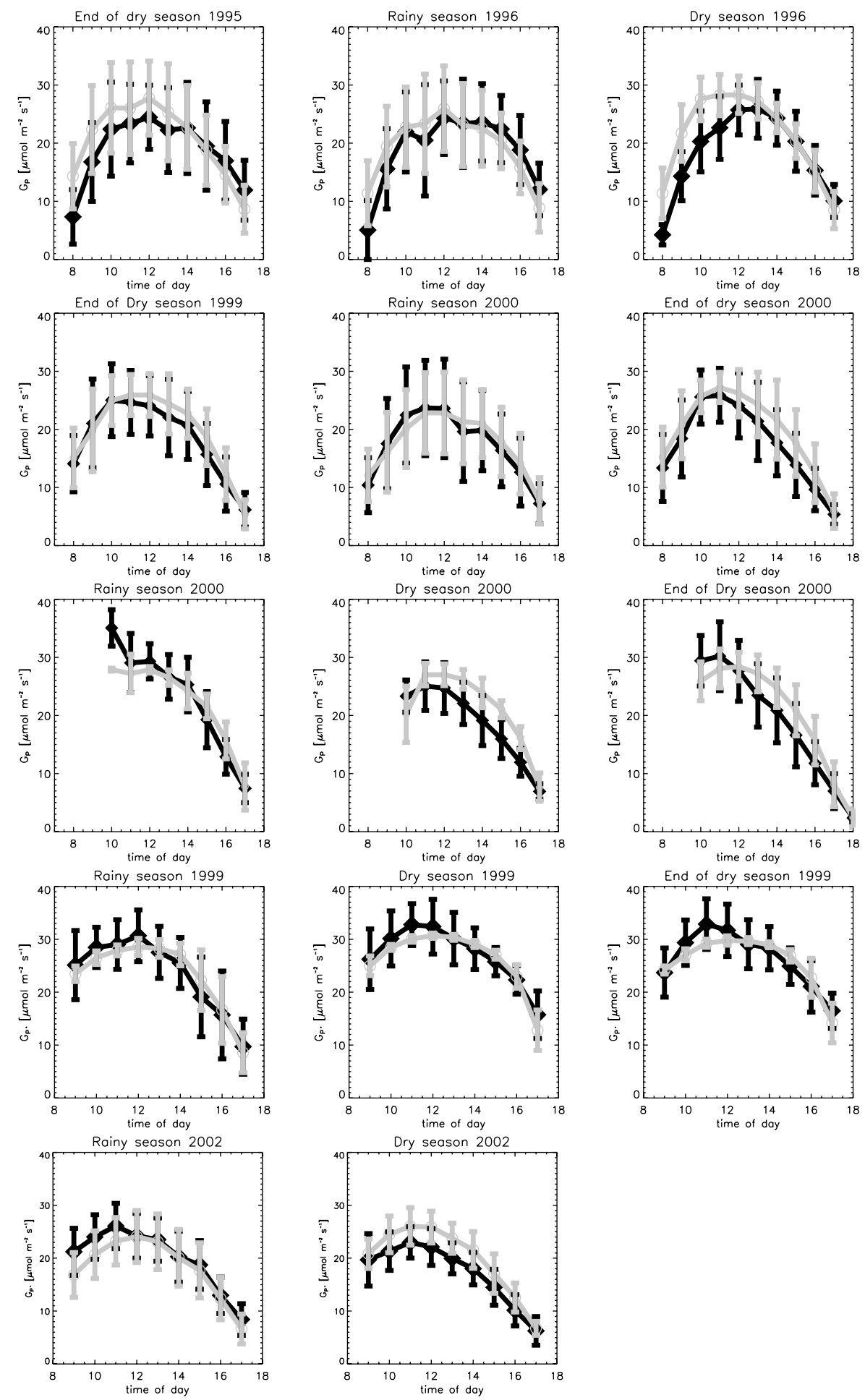

Fig. 3. Diurnal cycle of observed (black) and simulated (grey) $G_{P}$. 

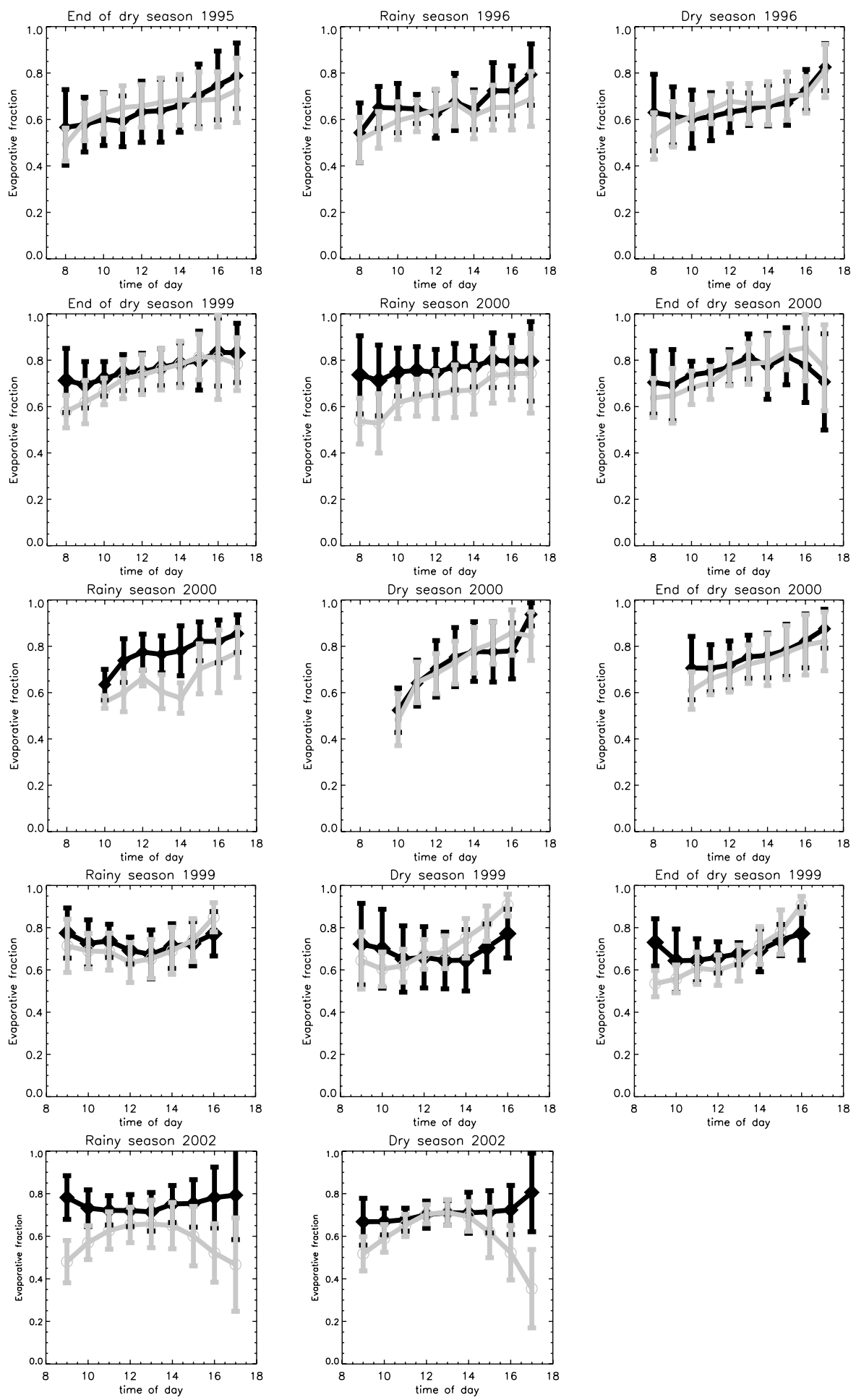

Fig. 4. Mean diurnal cycle of observed (black) and simulated (grey) evaporative fraction. 
Table 5. Parameters for sun/shade simulations at each site.

\begin{tabular}{llllll}
\hline & Man C14 & Man K34 & Jaru & Tapajos & Caxiuana \\
\hline$V_{\max }$ top canopy $\left(\mu \mathrm{mol} \mathrm{m}^{2} \mathrm{~s}^{-1}\right)$ & 52.3 & 40. & 51.89 & 47.49 & 32.11 \\
$J_{\max } / V_{\max }$ & 1.9 & 1.9 & 1.82 & 2.96 & 1.9 \\
Quantum yield, $\Phi$ & 0.4 & 0.35 & 0.4 & 0.16 & 0.5 \\
Theta, $\theta^{*}$ curvature factor & 0.7 & 0.7 & 0.7 & 0.7 & 0.7 \\
$S_{J}\left(\mathrm{~J} \mathrm{~mol}^{-1} \mathrm{~K}^{-1}\right)$ & 693.124 & 693.124 & 693.124 & 693.124 & 693.124 \\
$H_{J}\left(\mathrm{~J} \mathrm{~mol}^{-1}\right)$ & 220000 & 220000 & 220000 & 220000 & 220000 \\
Lambda, $\lambda\left(\mathrm{mol} \mathrm{mol}^{-1}\right)$ & 1200 & 2000 & 2000 & 5000 & 1800 \\
LAI $\left(\mathrm{m}^{2} \mathrm{~m}^{-2}\right)$ & 5.63 & 4.4 & 4.0 & 6.5 & 5.43 \\
Canopy $V_{\max }\left(\mu \mathrm{mol} \mathrm{m}^{2} \mathrm{~s}^{-1}\right)$ & 185.1 & 127.8 & 118.5 & 100.2 & 109.7 \\
\hline
\end{tabular}

Table 6. Statistics of model-data comparison for $G_{P}^{*}$ during the seasons tested. The regression model is modelled flux $=a \times$ measured (or estimated from eddy correlation) flux.

\begin{tabular}{lllcc}
\hline Site & Season & $a$ & $R^{2}$ & RMSE* \\
\hline Manaus C14 & End of dry 1995 & 1.08 & 0.94 & 5.29 \\
Manaus C14 & Wet 1996 & 0.96 & 0.94 & 5.20 \\
Manaus C14 & Dry 1996 & 1.1 & 0.95 & 5.29 \\
Manaus K34 & End of dry 1999 & 1.03 & 0.96 & 4.36 \\
Manaus K34 & End of dry 2000 & 1.08 & 0.96 & 4.47 \\
Manaus K34 & Rain 2000 & 0.97 & 0.95 & 4.36 \\
Jaru & Rain 2000 (all data) & 0.96 & 0.96 & 4.00 \\
Jaru & Dry 2000 (all data) & 1.13 & 0.96 & 4.35 \\
Jaru & End of dry 2000 (all data) & 1.04 & 0.95 & 5.00 \\
Caxiuana & Rain 1999 (all data) & 0.96 & 0.96 & 4.58 \\
Caxiuana & Dry 1999 (all data) & 0.96 & 0.97 & 4.24 \\
Caxiuana & End of dry 1999 (all data) & 0.95 & 0.97 & 4.24 \\
Tapajos & Rain 2002 (all data) & 0.90 & 0.92 & 5.29 \\
Tapajos & Dry 2002 (all data) & 0.95 & 0.93 & 5.29 \\
\hline
\end{tabular}

However, under the current parameterisation simulated $\delta^{13} \mathrm{C}$ over predicts the observed $\delta^{13} \mathrm{C}$ (i.e. simulated values are less negative than observations) (Table 7), meaning that the modelled $C_{i} / C_{a}$ is lower than what is suggested by the observations. Measured values of $\delta^{13} \mathrm{C}$ could only be explained by the model using a higher $\lambda$ than $1200 \mathrm{~mol} \mathrm{~mol}^{-1}$. However, with a higher $\lambda$, the model predicts a higher evaporation rate, consequently increasing the simulated evaporative fraction, which leads to an over prediction of observed energy partition (not shown).

\subsubsection{Man K34}

In terms of carbon uptake, there is good agreement between observations and simulations (see Table 6 for statistics), with only an $8 \%$ model overestimation during the end of the dry season in 2000. From the comparison of observed and simulated mean diurnal cycle of net photosynthetic uptake
Table 7. Observed (at Jaru from Ometto et al., 2006 and from Fyllas et al., 2009 for the remaining sites) and simulated $\delta^{13} \mathrm{C}$.

\begin{tabular}{|c|c|c|}
\hline Site & & $\delta^{13} \mathrm{C}(\% \circ)$ \\
\hline \multirow[t]{5}{*}{ Manaus C14 } & Measured & $32.05 \pm 2.0$ \\
\hline & Simulated with $\lambda=1200 \mathrm{~mol} \mathrm{~mol}^{-1}$ & \\
\hline & End of dry season 1995 & -26.95 \\
\hline & Rainy season 1996 & -25.49 \\
\hline & Dry season 1996 & -24.56 \\
\hline \multirow[t]{5}{*}{ Manaus K34 } & Measured & $-31.6 \pm 1.6$ \\
\hline & Simulated with $\lambda=2000 \mathrm{~mol} \mathrm{~mol}^{-1}$ & \\
\hline & End of dry season 1999 & -29.03 \\
\hline & End of dry season 2000 & -29.15 \\
\hline & Rainy season 2000 & -30.99 \\
\hline \multirow[t]{5}{*}{ Jaru } & Measured & $-32.3 \pm 2.0$ \\
\hline & Simulated with $\lambda=2000 \mathrm{~mol} \mathrm{~mol}^{-1}$ & \\
\hline & Rainy season 2000 & -30.47 \\
\hline & Dry season 2000 & -28.92 \\
\hline & End of dry season 2000 & -29.7 \\
\hline \multirow[t]{5}{*}{ Caxiuana } & Measured & $-32.5 \pm 1.7$ \\
\hline & Simulated with $\lambda=1800 \mathrm{~mol} \mathrm{~mol}^{-1}$ & \\
\hline & Rainy season 1999 & -29.84 \\
\hline & Dry season 1999 & -29.01 \\
\hline & End of dry season 1999 & -29.32 \\
\hline \multirow[t]{4}{*}{ Tapajos } & Measured & $-31.8 \pm 1.3$ \\
\hline & Simulated with $\lambda=5000 \mathrm{~mol} \mathrm{~mol}^{-1}$ & \\
\hline & Rain 2002 & -28.95 \\
\hline & Dry 2002 & -30.18 \\
\hline
\end{tabular}

(Fig. 3), we do, however, find a bias in the model to simulate higher $G_{P}$ during afternoons compared with estimates from eddy correlation, which coincides with higher radiation values in the light response curve (Fig. 2). Closer inspection reveals that this is linked to high vapour pressure deficit $\left(D_{C}\right)$ and air temperatures usually after 11:00 local time. This problem could be linked to the stomatal conductance model used not being sufficiently sensitive to such conditions. The sensitivity of the model was tested using different $\lambda$, values (results not shown). Nevertheless, the bias towards high $D_{C}$ and high temperatures persisted. 
According to Lloyd et al. (2009) and Fyllas et al. (2009), $\delta^{13} \mathrm{C}$ at the top of the canopy varies within a range of $(-30$ and $-34 \%$ ) with a mean value of $-32.05 \pm 2.0$ (\%o) from leaves collected at all heights, implying the sun and shade simulations are probably satisfactory in terms of modelled carbon exchange during all seasons (Table 7).

Energy partition was reasonably well simulated in the dry and end of dry season with the exception of the rainy season of 2000 where the model under-estimated the measured evaporative fraction (Fig. 4). Note that during the season when the best model data fit was obtained for carbon uptake (i.e. rainy season 2000), with closest simulated $\delta^{13} \mathrm{C}$ to observations, the worst fit for energy partition was obtained.

A sensitivity test showed that the model fit to observed evaporative fraction during the rainy season of 2000 can be improved by artificially increasing the $\lambda$ parameter from 2000 to $3000 \mathrm{~mol} \mathrm{~mol}^{-1}$. However, increasing $\lambda$ to $3000 \mathrm{~mol} \mathrm{~mol}^{-1}$ changes the partition between latent and sensible heat (increasing evaporation rates), improving the model comparison to evaporative fraction but at the cost of a decrease in the simulated $\delta^{13} \mathrm{C}$ (more negative) which leads to model underestimation of $\delta^{13} \mathrm{C}$ with respect to the measurements (results not shown).

\subsubsection{Jaru}

Simulated carbon uptake was best during the rainy and end of the dry seasons. However, the model overestimated observed carbon uptake by $13 \%$ during the dry season (Figs. 24). As for Manaus K34, the model has a bias towards overestimating net carbon uptake after midday, which is linked to high $D_{C}$ and high air temperature conditions. Nevertheless, the model obtains a good comparison to leaf carbon isotope measurements (Table 7). In terms of energy partition, the model agrees with the observations during the dry and end of dry seasons but underestimates evaporation rates during the rainy season. Again, as for Manaus K34, the best model fit to observations for photosynthesis is obtained at the cost of the worst model fit to observations of energy partition.

As the model was calibrated on data from the end of the dry season at all sites, a tendency to overestimate net carbon uptake fluxes during the dry season was not totally unexpected and could be explained as follows by a variety of phenomena, perhaps acting in concert: (1) decreases in canopy conductance due to higher $D_{C}$ during the dry season, (2) decreases in canopy conductance due to low soil water availability and (3) underestimation of the prescribed soil respiration used to calculate $G_{P}$ from eddy correlation and (4) reductions of canopy LAI due to leaf fall. Hereafter, each possibility is explored.

(1) Decreases in canopy conductance due to high $D_{C}$ during the dry season Measured values of $D_{C}$ during the dry season at this site in year 2000 were higher than during the rainy and end of dry season. The model over prediction of carbon uptake during this time could be linked to an insufficient stomatal closure at high $D_{C}$. Aiming to improve the model fit to carbon uptake, $\lambda$, was therefore artificially decreased from $2000 \mathrm{~mol} \mathrm{~mol}^{-1}$ to $1000 \mathrm{~mol} \mathrm{~mol}^{-1}$ and a very good fit to carbon uptake observations was then obtained. However, this resulted in a reduced simulated evaporative fraction, with values lower than observed (not shown). Under this parameterisation, simulated $\delta^{13} \mathrm{C}(-24.65)$ is much less negative than observed $(-32.3 \pm 2.0)$.

(2) Decreases in canopy conductance due to low soil water availability

According to von Randow et al. (2004), during 2000 no apparent direct effects of soil moisture deficit on canopy gasexchange were detectable. Therefore, it seems unlikely that modelled fluxes overestimation during 2000 are a consequence of lower canopy conductances due to soil moisture deficits. In another modelling approach, Lloyd et al. (1995) used eddy correlation flux data for the same site during dry and wet seasons of 1992 and 1993 and also found no indication of soil moisture deficits on canopy carbon uptake once the $D_{C}$ effects had been taken into account. Indeed, von Randow et al. (2004) measured the soil moisture profile down to $3.4 \mathrm{~m}$ for the period February 1999-September 2002 and found indications of ongoing water extraction from depth, especially during the dry season, this being attributed to continued root water uptake to satisfy transpirational demands, although some lateral drainage was not excluded.

(3) Low values of prescribed soil respiration rate used to calculate $G_{P}$ from eddy correlation

Ecosystem respiration at this site was estimated using soil respiration that was assumed diurnally and seasonally invariant, as there is little indication of seasonal differences in efflux rates from rainforest soil at Jaru and near constant soil temperatures as already discussed by Meir et al. (1996) and Lloyd et al. (1995). However, it has been shown that for other sites (Davidson et al., 2000; Sotta et al., 2004) soil water may play an important role in regulating the $\mathrm{CO}_{2}$ efflux from the soil especially in dry periods during and soon after precipitation events. Davidson et al. (2000) reports optimum conditions for soil respiration at intermediate water contents with decreases in respiration at water contents both above and below that value. Therefore, soil respiration could have been higher than assumed during the dry season. However, Meir et al. (2008) conclude that short term moisture limitation can lead to significant reductions of total soil respiration and recognize the lack of a mechanistically and spatially accurately description of the response of soil respiration to variations in soil moisture across the Amazon basin.

\section{(4) Possible reductions of canopy LAI due to leaf fall}

A large increase in litterfall at the onset of the dry season has been well documented for the Manaus region (Klinge, 1968; Luizao and Schubart, 1987). If this increase in litterfall gives rise to a decrease in LAI, forest photosynthetic carbon uptake during the dry season would naturally be expected to decrease. To test this possibility, model runs were performed 
for the dry season assuming a $10 \%$ and $20 \%$ decrease in total LAI, respectively (Nepstad et al., 2002; Asner et al., 2004). But even in these cases, simulated $G_{P}$ overestimates the observations (results not shown).

\subsubsection{Caxiuana}

For this site a good model fit to observed mean diurnal cycle and light response of net carbon uptake for all seasons was obtained (Figs. 2-4). Simulated $\delta^{13} \mathrm{C}$ values are in within the higher range of the reported values from this site (Table 7). For this site, no $D_{C}$ bias to carbon uptake was obtained, although there were fewer data points available here than for other sites (Man K34 and Jaru). However, in terms of energy partition, the model overestimates afternoon measurements during all seasons, which could be linked to an insensitive stomatal conductance model to higher afternoon $D_{C}$ and air temperatures.

\subsubsection{Tapajos}

The sun/shade model provided a good fit to the mean observed diurnal cycle and light response of gross carbon uptake for this site, (Figs. 2-4) but with a $10 \%$ underestimation in observed net carbon uptake during the rainy season. Notice the linear response of simulated photosynthesis at all light levels. This is driven by the obtained parameterisation for this site using the optimization procedure, (i.e. a high $J_{\max } / V_{\max }$ ratio of 2.92 , a very low quantum yield of 0.16 and high $\lambda$, compared to that obtained at the other sites). A combination of a very high $J_{\max } / V_{\max }$ ratio and low quantum yield of photosynthesis promotes light limitation of photosynthesis in the model at most radiation values. Again, the model has a bias towards over predicting observations at the highest values of $D_{C}$ and air temperature. Simulated $\delta^{13} \mathrm{C}$ is on the higher end the observed range at this site (Table 7). Additionally, under this parameterisation the model under predicts observed evaporative fraction in the early morning and late afternoon conditions.

\section{Scaling up to basin level}

An attempt to produce a canopy scale function to scale up simulations to basin level is also presented. Such scaling up is made based on the model calibration and evaluation for the five tower sites. The scaling function can be used to parameterise the model at other sites, using the linear regression obtained from relating the best $V_{\max }$ obtained from parameterisations at each of the 5 sites to its correspondent foliar N. Further, given that (1) tropical forest might be phosphorus instead of nitrogen limited and (2) that phosphorus (P) plays a regulatory role in the partition of the products of photosynthesis directly affecting the activity of the Calvin cycle and therefore affecting the activity of Rubisco carboxylation, relationships between $V_{\max }$ and foliar $\mathrm{P}$, and the ratio of foliar $\mathrm{N}$ to foliar $\mathrm{P}$ are also explored.
Phosphate limitation to photosynthesis may be linked to a failure in the capacity of starch and sucrose synthesis to match the capacity of the production of triose phosphates in the Calvin cycle, usually when both $C_{i}$ and light are high. The result is an inadequate rate of release of inorganic phosphate in the chloroplast to recycle the $\mathrm{P}$ sequestered in the production of triose phosphates. In this case inorganic phosphorus can limit photosynthesis (Harley and Sharkey,1991). This has been included in the biochemistry of C3 photosynthesis (Collatz et al., 1991). Implementation of the TPU limitation to photosynthesis in the Collatz et al. (1991) model suggests that the capacity of export or utilization of the products of photosynthesis is approximately equal to the maximum photosynthetic uptake at saturating irradiance, defining the TPU limitation as

$J_{s}=V_{\max } / 2$

where $J_{S}$ is the export capacity or utilization of the photosynthetic products (most likely sucrose synthesis). Additionally, several studies have shown $\mathrm{P}$ deficiency to reduce photosynthesis (Terry and Ulrich, 1973; Sharkey, 1985; Brooks, 1986; Jacob and Lawlor, 1992; Campbell and Sage, 2006). However, the mechanisms by which $\mathrm{P}$ deficiency affects photosynthesis are not well understood (Campbell and Sage, 2006). Other possible mechanisms by which $P$ deficiency affects photosynthesis are via reductions in Rubisco activity (Brooks, 1986; Brooks et al., 1988), reductions in the rate of RuBP regeneration, reduction of quantum yield due to photoinhibition caused by reduced efficiency of RuBP regeneration at low irradiances, and reductions in the Calvin cycle activity due to reductions in key regulatory enzymes of the cycle (Brooks, 1986; Campbell and Sage, 2006). From the above limited understanding on the mechanisms by which leaf phosphorus affects photosynthesis, we decided to relate $V_{\text {max }}$ obtained in this study to leaf P for the 5 study sites.

Two methods were used to scale up to the basin level, one based on leaf $\mathrm{N}$ and the other on leaf P. Linear relationships between mean leaf $\mathrm{N}$ (and leaf $\mathrm{P}$ ) content per dry weight and per leaf area, using data outlined in Fyllas et al. (2009) were used, and best fitted $V_{\max }$ at each site were used. However, because $\Phi$ (Eq. A6) affects to some extent the efficiency of $V_{\text {max }}$, to relate $V_{\max }$ to leaf $\mathrm{N}$ and leaf $\mathrm{P}$ under the same conditions, $V_{\max }$ and $J_{\max } / V_{\max }$ were fitted again with a fixed quantum yield of 0.4 , with results shown in Table 8 .

Using this parameterisation for the sun/shade model, similar results are obtained at all sites compared to what was obtained except at Tapajos. At Tapajos, the model overestimated gross photosynthesis by $15 \%$ and $20 \%$ during the dry and wet season, respectively, with a better comparison to observed evaporative fraction than obtained earlier (Fig. B3). The reason for this overestimation is linked to a much higher quantum yield $(0.4$ vs. 0.16$)$ and a much lower $J_{\max } / V_{\max }$ ratio ( 1.88 vs. 2.96$)$ than obtained in the site-specific simulations. 
Table 8. Fitted $V_{\max }, J_{\max } / V_{\max }$ with $(\Phi=0.4)$ at each site.

\begin{tabular}{lllllll}
\hline Site & $\begin{array}{l}V_{\max } \text { top } \\
\text { fitted again } \\
\left(\mu \mathrm{mol} \mathrm{m} \mathrm{m}^{-2} \mathrm{~s}^{-1}\right)\end{array}$ & $\begin{array}{l}\text { original } V_{\max } \\
\left(\mu \mathrm{mol} \mathrm{m} \mathrm{m}^{-2} \mathrm{~s}^{-1}\right)\end{array}$ & $\begin{array}{l}J_{\max } / V_{\max } \\
\text { fitted again }\end{array}$ & $\begin{array}{l}J_{\max } / V_{\max } \\
\text { original }\end{array}$ & $\begin{array}{l}\Phi \\
\text { fixed }\end{array}$ & $\begin{array}{l}\Phi \\
\text { original }\end{array}$ \\
\hline Manaus C14 & & 52.3 & & 1.92 & & 0.4 \\
Manaus K34 & 37.8 & 40 & 1.9 & 1.9 & 0.4 & 0.35 \\
Jaru & 51.89 & 51.89 & 1.82 & 1.82 & 0.4 & 0.4 \\
Caxiuana & 39.44 & 32.11 & 1.83 & 1.9 & 0.4 & 0.5 \\
Tapajos & 40 & 47.49 & 1.88 & 1.96 & 0.4 & 0.16 \\
\hline
\end{tabular}

Table 9. Statistics of regressions of $V_{\max }$ (with $\Phi=0.4$ ) in area and DW basis against foliar $\mathrm{N}$ and foliar $\mathrm{P}$, with $a$ and $b$ as intercept and slope of the linear relationship obtained.

\begin{tabular}{llllll}
\hline & & $a$ & $b$ & $R^{2}$ & $p$-value \\
\hline$V_{\max }\left(\mu \mathrm{mol} \mathrm{g}^{-1} \mathrm{~s}^{-1}\right)$ & vs. $\mathrm{P}\left(\mathrm{mg} \mathrm{g}^{-1}\right)$ & 0.18 & 0.38 & 0.3 & 0.45 \\
$V_{\max }\left(\mu \mathrm{mol} \mathrm{m}^{-2} \mathrm{~s}^{-1}\right)$ & vs. $\mathrm{P}\left(\mathrm{g} \mathrm{m}^{-2}\right)$ & 17.9 & 386.9 & 0.41 & 0.4 \\
$V_{\max }\left(\mu \mathrm{mol} \mathrm{g}^{-1} \mathrm{~s}^{-1}\right)$ & vs. $\mathrm{N}\left(\mathrm{mg} \mathrm{g}^{-1}\right)$ & 0.36 & 0.004 & 0.03 & 0.35 \\
$V_{\max }\left(\mu \mathrm{mol} \mathrm{m}^{-2} \mathrm{~s}^{-1}\right)$ & vs. $\mathrm{N}\left(\mathrm{g} \mathrm{m}^{-2}\right)$ & 30.8 & 6.2 & 0.08 & 0.32 \\
$V_{\max }\left(\mu \mathrm{mol} \mathrm{g}^{-1} \mathrm{~s}^{-1}\right)$ & vs. $\mathrm{N}\left(\mathrm{mg} \mathrm{g}^{-1}\right) / \mathrm{P}_{\left(\mathrm{mg} \mathrm{g}^{-1}\right)} 1.2$ & -0.02 & 0.65 & 0.033 \\
$V_{\max }\left(\mu \mathrm{mol} \mathrm{m}^{-2} \mathrm{~s}^{-1}\right)$ & vs. N $\left(\mathrm{g} \mathrm{m}^{-2}\right) / \mathrm{P}\left(\mathrm{g} \mathrm{m}^{-2}\right)$ & 95.1 & -1.59 & 0.49 & 0.052 \\
\hline
\end{tabular}

For all sites $V_{\max }$ in dry weight (DW) and on an area basis from Table 8 were then related to upper canopy average foliar $\mathrm{N}$ and P (DW and area basis) as in Fyllas et al. (2009) as shown in Fig. 5 (see data used in Table 4), with statistics from the correspondent linear relationships shown in Table 9.

$V_{\max }$ on an area basis was converted to (DW) using associated measurements of leaf mass per unit area (Fyllas et al., 2009). The highest correlations was then for leaf $\mathrm{P}$ with $V_{\max }$ on area basis. In contrast to the relationships of $V_{\max }$ with leaf $\mathrm{N}$ which have very low regression coefficients and almost a flat slope indicating no change of $V_{\max }$ with leaf N. Additionally, relationships of $V_{\max }$ in area and DW basis against leaf $\mathrm{P}$ and against the ratio of leaf $\mathrm{N}$ to leaf $\mathrm{P}$ are shown in Fig. 5 (bottom row) with associated statistics given in Table 9. The $V_{\max }$ vs. Leaf $\mathrm{P}$ (DW and area basis) and $V_{\max }$ vs. leaf N/leaf $\mathrm{P}$ predict increasing $V_{\max }$ and both are statistically significant.

\subsection{Model parameterization}

Figure 6 shows a comparison of top of the canopy $V_{\max }$ obtained in this study (with quantum yield fixed to 0.4 ) against available measurements ( 3 sites) and against $V_{\max }$ calculated from linear regressions of $V_{\text {max }}$ against leaf $\mathrm{N}$ obtained from measurements at individual sites (available at 3 sites). The $V_{\max }$ values obtained (circles on Fig. 6) are on the upper end of the range, closest to the measured values at the 3 avail- able sites (crosses in Fig. 6). The large difference between $V_{\text {max }}$ obtained in this study and those predicted from linear relationships of $V_{\max }$ and leaf $\mathrm{N}$ from other sites, are likely due to the relationships reflecting specific conditions of the individual sites. In any case, $V_{\max }$ predicted from the regression based on the Carswell et al. (2000) data is the lowest in Fig. 6. This is because leaf $\mathrm{N}$ from this data set are the highest from all data sets considered here. Moreover, leaf $\mathrm{N}$ reported from Carswell et al. (2000) for Man C14 are also higher than those measured at the same site by Ometto et al. (2006) and reported by Fyllas et al. (2009).

The quantum efficiency for $\mathrm{CO}_{2}$ fixation "quantum yield", used in Eq. (A6) to estimate the irradiance absorbed by photosystem II, was one of the parameters initially fitted at each site. Farquhar et al. (1980) defined a theoretical upper limit to quantum yield (when $f=0$ in Eq. A6) in the absence of oxygenation set by NADPH or by ATP requirement of 0.5 and 0.4, respectively. Equation A6 an be rewritten using $\alpha$, which intrinsically includes $f$ and $\Phi$, this providing an alternative definition of the intrinsic quantum efficiency for $\mathrm{CO}_{2}$ uptake. The form of Eq. (10) is the most commonly used in modelling studies and $\alpha$ is the parameter value usually reported.

$I_{2}=I_{0} \times(1-r-t) \alpha$

Even though the theoretical upper limit for $\Phi$ is $0.4-0.5$ (i.e. $\alpha$ of $0.125-0.11$ ), measured values of $\alpha$ range considerably; 
Table 10. Comparison of $\alpha$ as reported in various studies and obtained in this study. Unit conversion is done assuming that to produce 1 mol of $\mathrm{CO}_{2}, 4$ electrons are needed.

\begin{tabular}{|c|c|c|c|c|}
\hline Study & Use & $\alpha\left[\mathrm{mol} \mathrm{CO}_{2} \mathrm{~mol}^{-1} \mathrm{PAR}\right]$ & $\alpha$ [mol electrons $\mathrm{mol}^{-1}$ photons $]$ & $\theta$ \\
\hline Ehleringer and Bjorkman (1977) & measured & 0.073 & 0.29 & \\
\hline Ehleringer and Pearcy (1983) & measured & 0.052 & 0.22 & \\
\hline Long et al. (1993) & measured & 0.093 & 0.372 & \\
\hline \multirow[t]{2}{*}{ Farquhar et al. (1980) } & theoretical & 0.125 & 0.5 & \\
\hline & upper limit of $\alpha$ & 0.11 & 0.44 & \\
\hline Thornley (2002) & $\begin{array}{l}\text { used for model } \\
\text { parameterisation }\end{array}$ & 0.05 & 0.2 & \\
\hline Wand and Leuning (1998) & $\begin{array}{l}\text { used for model } \\
\text { parameterisation }\end{array}$ & 0.096 & $0.385^{\mathrm{a}}$ & \\
\hline Harley et al. (1992) & $\begin{array}{l}\text { used for model } \\
\text { parameterisation }\end{array}$ & 0.06 & 0.24 & \\
\hline Collatz et al. (1991) & $\begin{array}{l}\text { used for model } \\
\text { parameterisation }\end{array}$ & 0.08 & 0.32 & 0.95 \\
\hline Leuning (1990) & $\begin{array}{l}\text { fitted to leaf gas } \\
\text { exchange measurements }\end{array}$ & {$[0.032-0.066]^{\mathrm{a}}$} & $0.128-0.264$ & 0.95 \\
\hline Leuning (1995) & used for model & $0.05^{\mathrm{a}}$ & $0.2^{\mathrm{a}}$ & 0.95 \\
\hline Leuning et al. (1995) & parameterisation & & 0.9 & \\
\hline Medlyn et al. (2002) & used for model & 0.093 & 0.372 & 0.9 \\
\hline & parameterisation & $0.074^{\mathrm{b}}$ & 0.29 & \\
\hline de Pury and Farquhar (1997) & $\begin{array}{l}\text { used for model } \\
\text { parameterisation }\end{array}$ & 0.106 & 0.425 & 0.7 \\
\hline This study & used for model & & & \\
\hline Man C14 $(\Phi=0.40)$ & parameterisation & 0.085 & 0.34 & 0.7 \\
\hline Man K34 $(\Phi=0.35)$ & & 0.074 & 0.3 & 0.7 \\
\hline $\operatorname{Jaru}(\Phi=0.35)$ & & 0.074 & 0.3 & 0.7 \\
\hline Tapajos $(\Phi=0.30)$ & & 0.063 & 0.25 & 0.7 \\
\hline Caxiuana $(\Phi=0.50)$ & & 0.106 & 0.425 & 0.7 \\
\hline
\end{tabular}

a Value including absorbed photon irradiance

$\mathrm{b}^{\mathrm{b}}$ Including leaf absorptance of 0.8
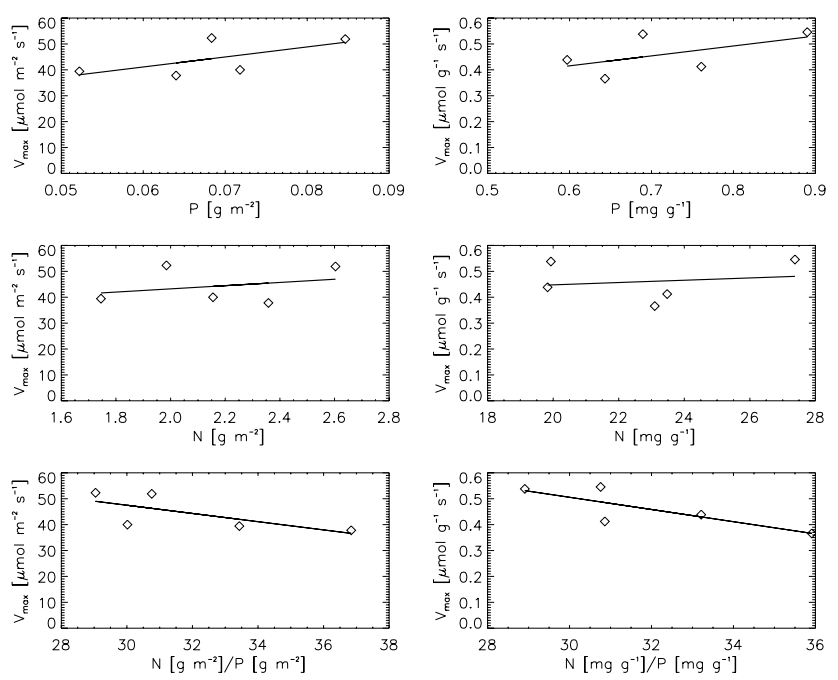

Fig. 5. Linear regressions obtained from best fitted $V_{\max }$ in DW and in area basis (with $\Phi=0.4$ ) against foliar N and foliar P in DW at five rainforest sites. for example $0.073(\Phi=0.29)$ (Ehleringer and Björkman, 1977), 0.052 ( $\Phi=0.22$ ) (Ehleringer and Pearcy, 1983) and 0.093 ( $\Phi=0.372$ ) (Long et al., 1993). A list of reported $\alpha$ values used or determined in modelling studies is listed in Table 10. This shows that values obtained in this study are indeed within the published range of variation, with $\alpha$ for Caxiuana close to the theoretical upper limit for quantum yield. According to Leuning (1990), when fitting $\alpha$ and curvature parameter $\theta$ (Eq. A5) to gas exchange measurements, the obtained variation in $\alpha$ has little physiological meaning due to the interaction between $\alpha$ and $\theta$ that occurs during the non-linear curve fitting procedure. The curvature parameter $\theta$ has no mechanistic basis (Collatz et al., 1990), although it can be viewed as an indicator of the extent to which co-limitation (of light and Rubisco limitations) of photosynthesis is present with $\theta$ approaching 1 meaning that colimitation is minimized. But a certain level of co-limitation is always present (Woodrow and Berry, 1988). Values of $\theta$ in some of the modelling studies (listed in Table 10), include variations between 0.7 and 0.95 . Moreover, a recent 


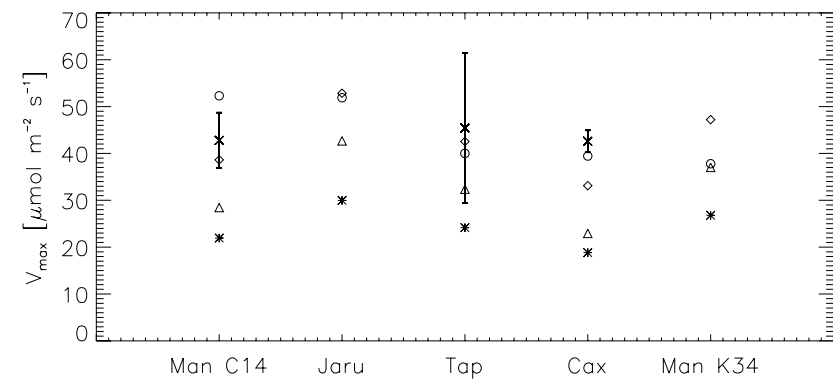

Fig. 6. Top leaf $V_{\max }$. Obtained from numerical fitting in this study are circles, measured at Manaus C14, Tapajos and Caxiuana, crosses, calculated from linear regression between measured $V_{\max }$ and leaf $\mathrm{N}$ at 3 at different canopy levels at 3 of the studied sites: Manaus C14 (Carswell et al., 2000), Caxiuana (Vale et al., 2000) and Tapajos (Domingues et al., 2005) (asterisks, triangles and rhombuses sign, respectively). See linear regressions used for calculations of $V_{\max }$ in Table B1.

modelling study using data for Jaru and Manaus C14 optimized parameters of the $C_{3}$ photosynthesis model and obtained an $\Phi$ of 0.15 and 0.2 and $\theta$ of 0.8 and 0.9 , respectively (Simon et al., 2005). Domingues et al. (2005) measured leaf photosynthesis at the same Tapajos forest site as used in this study. They adopted a fixed $\Phi$ of 0.19 following Ehleringer and Björkman (1977) fitting light response measurements of photosynthesis to a non-rectangular hyperbolic model. The curvature factors derived from such a fitting exercise ranged between 0.45 and 0.9 for most of the cases.

Variation in the parameterised value of $\Phi$ for the different sites of this study could thus simply be a result of a mathematical interaction between $\Phi$ and $\theta$ (here fixed to 0.7). On the other hand, as it was shown in Fig. B1, there do seem to be real differences in the slope of the light response of measured $N_{E}$ among sites which could have some physiological meaning. For example, differences in efficiency of photosynthetic uptake due to nutrient or other stresses which, from the analysis here not appear to be related to soil water deficits. Detailed measurements would be required to examine variation of $\Phi$ across sites. In summary, our fitting procedure produced parameter values within the ranges derived from theory, observation and values adopted by other modelling studies.

\subsection{Data}

Moreover, model parameters obtained from this fitting exercise and the model evaluation presented in this study are subject to the fidelity of the data used for model parameterisation and evaluation. The main limitations to this datamodel parameterisation and evaluation are associated with difficulties in estimating ecosystem respiration and the lack of energy balance closure. Due to spatial and seasonal vari- ability in soil respiration (Chambers et al., 2004; Silva de Souza, 2004), and with varying meteorological conditions (mainly precipitation regimes) during the measurement and model comparison periods, it is more than likely that there were differences between the measured respiration and those which we used at 3 of the studied sites. Another source of uncertainty in the ecosystem respiration is associated with the leaf respiration term. There is increasing evidence to show that leaf respiration rates are lower when plants are photosynthetically active (Brooks and Farquhar, 1985; Hoefnagel et al., 1998; Atkin et al., 1998, 2000), especially at high leaf temperatures. Unfortunately, biochemical models of gas exchange do not yet include these effects and neither did the leaf level parameters used in this study for comparisons against our obtained parameters. A recent study (Wohlfahrt et al., 2005) assessing daytime ecosystem respiration in a mountain meadow found that a failure to include light inhibition of canopy respiration resulted in an overestimation of daily estimates of ecosystem respiration and hence gross primary productivity from eddy correlation measurements. Their results suggest a reduction in estimated GPP from eddy correlation measurements on the order of 11$13 \%$ and $13-17 \%$ for a low and high estimate of the simulated maximum leaf-level reduction of dark respiration, respectively. Another study using eddy correlation data from various sites within Europe (Janssens et al., 2001) reports up to a $15 \%$ reduction in estimated total ecosystem respiration when considering daytime inhibition of leaf respiration. An alternative method to refine estimates of ecosystem respiration using eddy correlation measurements (Van Gorsel et al., 2007, 2008) is yet to be tested for the Amazon rainforest sites. The method uses the maximum of the sum of the turbulent flux and storage flux of $\mathrm{CO}_{2}$ in the early evening, and has been shown to be in close agreement with measurements from soil and plant respiration chambers at a moderately complex tophography. Such maximum, which is unaffected by advection (Van Gorsel et al., 2008) due to stable stratification conditions after sunset, is used to construct relationships between night time ecosystem exchange measurements, soil temperature and humidity which then can be used to predict ecosystem respiration at all times of day.

Furthermore, there are considerable uncertainties in eddy covariance measurements, especially above rain forest vegetation. For instance, there is a large sensitivity (10-25\% annually) to the treatment of low frequencies and nonhorizontal flow and delay corrections and data spikes (Kruijt et al., 2004). The total uncertainly in daytime measurements estimated for the Manaus K34 and Jaru site are \pm 12 and $32 \%$, respectively (Kruijt et al., 2004). In addition to these uncertainties in $N_{E}$, the estimates of total ecosystem respiration and use of modelled storage flux imposes an additional uncertainty to the comparison presented. Further, non-closure of the energy balance in the eddy covariance data (Aubinet et al., 2002; Massman and Lee, 2002) forced us to consider only energy partition in terms of evaporative 
fraction. Due to the high hour-to-hour variability in the measurements we also decided to test the model against mean diurnal cycles only.

In order to close the energy balance, fluxes of carbon and energy have been subject to different modes of data processing and post processing correction at each site (Malhi et al., 2002; Finnigan et al., 2003; Gash and Dolman, 2003; van der Molen et al., 2004). With respect to linear detrending, and accounting for low frequency contributions and "angle of attack dependent calibrations", in 2 out of 5 cases the energy balance improved with the magnitude of the $\mathrm{CO}_{2}$ fluxes increasing as well (Malhi et al., 2002; von Randow et al., 2004). In general, non-closure of the energy balance at four of the five sites implies a missing $\mathrm{CO}_{2}$ which may have contributed to the model/data mismatch. However, the extent to which this has occurred is unknown. After recalibration of fluxes for angle of attack and low frequency contributions, the energy and carbon fluxes increased (compared to data without this calibration) (Gash and Dolman, 2003; van der Molen et al., 2004). However, the level of improvement in percentage closure of energy fluxes differs from those improvements for carbon fluxes. Furthermore, A. Araújo (personal communication, 2004) obtained an increase of $8 \%$ on average for sensible, latent and $\mathrm{CO}_{2}$ fluxes after recalculating the fluxes including the angle of attack correction for the Man K34 site.

Higher rates of litterfall towards the end of the wet season/onset of dry season are well documented for some sites in the Amazon region (Klinge, 1968; Luizao and Schubart, 1987; Nepstad et al., 2002; Goulden et al., 2004). However the expected concurrent decrease in LAI has still not been measured. The phenology behind this phenomenon still needs better understanding. Besides satellite derived LAI, in situ measurements of seasonality in LAI are very scarce for the Amazon region. Nevertheless, according to Doughty and Goulden (2008a), in situ LAI seasonality is actually opposite to that derived from satellite measurements. Lacking in situ measurements for most sites, LAI seasonality was not included in any of the sites unless there were available LAI data (used only at the Caxiuana site). Seasonality in LAI may play a major role in driving seasonality of gross uptake at Caxiuana and Tapajos (Carswell et al. 2002; Goulden et al., 2004). A recent study using field work observations at one of the rainforest Tapajos sites (Doughty and Goulden, 2008a) reports that measured seasonality of GPP at this site could only be explained when taking into account, seasonal changes in (i) LAI, (ii) leaf age and (iii) leaf photosynthesis. Another study, measuring leaf level photosynthesis at a well drained and droughted forest at Caxiuana, during various dry and wet periods, concluded that the observed seasonality in maximum rates of photosynthesis at both well drained and droughted forest was not accompanied by any significant change in the photosynthetic parameters $V_{\max }, R_{D}, J_{\max }$, in most species, suggesting that the inhibition observed in $\mathrm{CO}_{2}$ carbon uptake in the dry season was mostly dictated by stom- atal closure (Vale et al., 2003). More experiments of this type are needed at different sites across the Amazon basin to understand the main factors controlling seasonality in carbon and water exchange at the different sites.

\subsection{Model evaluation}

Model bias towards overestimation of measured carbon uptake at high $D_{C}$ and temperature was usually linked to midday and afternoon values, the exceptions being Man C14 and Caxiuana. This indicates a model insensitivity to stomatal closure under these conditions. However, the observed decrease in $\mathrm{CO}_{2}$ uptake at high $D_{C}$ and air temperatures may not be caused by plant water stress per se because at least for the period studied, the original investigators have indicated that there were no indications of soil water stress at Tapajos (da Rocha et al., 2004; Goulden et al., 2004; Saleska et al., 2003) and at Jaru (von Randow et al., 2004). Manaus K34 was studied here only during the wet and end of dry periods. Furthermore, Mercado (2007) compared the performance of the model used here (also coupled to the sun and shade model) against two versions of the Ball and Berry (Ball et al., 1987) stomatal conductance model. The first version is the modified scheme by Leuning (1990) with dependence on relative humidity, and second version included a dependence on $D_{C}$ as modified by Leuning (Leuning, 1995). Both stomatal conductance models were coupled to the sun and shade model. Using the "Ball and Berry" or the "Lambda" model made no major difference to the simulated carbon uptake or to the quality of the residuals with either photosynthesis model. Lloyd et al. (1995) obtained similar results when comparing the same two stomatal conductance models coupled to a big leaf model at the Jaru site. This was not unexpected because theoretically both models embody the same principles. They incorporate the well known correlations between photosynthesis and stomatal conductance and describe $G_{S}$ using similar variables (i.e. $D_{C}$ or relative humidity at the leaf surface, $\mathrm{CO}_{2}$ uptake, and $\mathrm{CO}_{2}$ concentration at the leaf surface). Finally, Tuzet et al. (2003) suggest that model insensitivity to afternoon conditions (high $D_{C}$ and air temperatures) may result from inadequate/or in this case no coupling of stomatal conductance to the dynamics of water transport from soil to the roots and leaves. This may suggest the need for a stomatal conductance formulation that includes stomatal regulation taking into account both the external environment (demand) but also the dynamics of water movement from the soil/root to the leaf (supply) (Tyree, 2003; Buckley, 2005; Fisher et al., 2007). From soil moisture measurements at a neighboring site to that studied here at Tapajos, da Rocha et al. (2004) found night time water recharge and day time water withdrawal from roots down to $60 \mathrm{~cm}$ up to the top $5 \mathrm{~cm}$ during dry and wet periods, with soil at $2 \mathrm{~m}$ depth remaining moist all year round implying full access to soil water throughout the dry season. 
Another explanation for the model mismatch at high temperature and $D_{C}$ conditions could be linked to decrease in forest photosynthesis due to high temperatures. Doughty and Goulden (2008b) measured leaf level canopy temperatures in parallel with canopy and leaf level photosynthesis and evaporation. From their observations, these authors suggest that the forest (neighbor to the Tapajos km 67 studied here) appears to be close to a high temperature threshold above which photosynthesis declines. However, Lloyd and Farquhar (2008) using observations, model parameterizations of leaf level photosynthesis with known temperature sensitivities, and climate model output conclude that there is no evidence for tropical forest being close to a temperature threshold or to the upper temperature limit for optimum photosynthesis. Their model suggests decreases in photosynthesis above $30^{\circ} \mathrm{C}$, which the authors explain as a stomatal conductance response to high $D_{C}$. The simulations presented in this study used a value of $39^{\circ} \mathrm{C}$ as the maximum optimum temperature dependency of electron transport rate, obtained fitting eddy correlation measurements to the sun and shade model at the Manaus C14 site (Mercado et al., 2006). Lloyd et al. (1995) obtained a value of $43^{\circ} \mathrm{C}$ when fitting a big leaf model to eddy correlation measurements at the Jaru site. More measurements of leaf level temperature response at different rainforest sites is needed to check if temperature threshold measured at Tapajos (Doughty and Goulden, 2008b) prevails elsewhere. Finally, another possible explanation for the decline in photosynthesis and stomatal closure at high $D_{C}$ and temperature conditions might be related to a reduction in the activation state of Rubisco due to the high temperature being above its thermal optimum (Sage and $\mathrm{Ku}-$ bien, 2007). If this was the case, the capacity of deactivated Rubisco would be needed to be incorporated into the photosynthesis models.

The underestimation of simulated latent heat fluxes during the rainy season at 3 of 5 sites could mean the model needs larger simulated stomatal conductances to account for the observations. For instance, the best simulated energy partitioning was obtained when the fit for carbon uptake was on the upper range (Table 5). This was the case for end of dry and dry seasons at Manaus C14, end of dry season at Manaus K34 and the dry season in Jaru. On the other hand, when the fit for carbon uptake was on the lower range there was usually a model tendency to underestimate the mean observed diurnal cycle of evaporative fraction. This was the case during all seasons at Caxiuana, Tapajos and rainy seasons at Manaus C14 and K34 and rainy season at Jaru. Furthermore, at Tapajos, after refitting with a fixed quantum yield of 0.4 , the fit for carbon uptake was overestimated observations by 20 and $15 \%$ during the rainy and wet seasons, respectively, whilst obtaining a better fit to evaporative fraction (Fig. B3).

Furthermore, a larger simulated stomatal conductance could be obtained either by increasing the $\lambda$ parameter from the stomatal conductance model or by increasing the simulated assimilation rate. Sensitivity analysis showed that by increasing $\lambda$, the $C_{i} / C_{a}$ ratio increased and therefore the simulated $\delta^{13} \mathrm{C}$ decreased (becoming more negative). In general, this led to model underestimation of $\delta^{13} \mathrm{C}$. The second option would be to increase simulated $G_{P}$ which automatically would lead to model overestimation with respect to the observations. However, associated with a failure to close the energy balance is a probably also a non-measured $\mathrm{CO}_{2}$ flux signal (Aranibar et al., 2006), implying a higher $G_{P}$ than currently measured. A consequence of a higher simulated $G_{P}$ is a concurrent increase in simulated latent heat fluxes which would improve the model comparison to evaporative fraction measurements.

Generally, besides the $D_{C}$ bias towards overestimation (found at 3 of 5 sites), the sun and shade model performed well in simulating the carbon uptake at all tower sites, a finding supported by the $\delta^{13} \mathrm{C}$ evaluation, with a model tendency to underestimate energy partition at some sites during the rainy season. Morales et al. (2005) evaluated 4 process-based models against eddy correlation flux data at 15 European sites and found no single model performed well for both carbon and water fluxes. According to Morales et al. (2005), two models performed better at simulating carbon fluxes, the remaining two models in simulating water fluxes. Another modelling study using the land surface scheme of the Hadley Centre GCM carried out an evaluation with the same data set as used here for the Man K34 site, and obtained better results for carbon uptake than for energy partition (Mercado et al., 2007).

\subsection{Scaling up to basin level}

Unfortunately there were only five data points to derive relationships between $V_{\max }$ and leaf $\mathrm{N}$ and leaf $\mathrm{P}$, and the slope and high correlation coefficient for the correlations between $V_{\max }$ and leaf $\mathrm{P}$ (in area and DW basis) is due to a one data point which has the highest leaf $\mathrm{P}$ in the data set, corresponding to the Jaru site. However, the linear relationships of $V_{\max }$ against leaf $\mathrm{P}$ (in area basis) from this study are comparable to those from leaf level measurements from tropical forest in West Africa with more fertile soil types (Domingues, unpublished data) (Fig. 7).

These results suggest the possibility that foliar $\mathrm{P}$ or the ratio of Foliar $\mathrm{N}$ to $\mathrm{P}$ may emerge as good predictors for the photosynthetic capacity for Amazonian forests. This needs to be verified by field observations and unfortunately, the eddy correlation systems have yet to be installed at sites where leaf phosphorus concentrations are higher than at the five Brazilian sites used here, all of which were on relatively infertile soils. This is important, because Fyllas et al. (2009) substantially higher average foliar P for sites in western Amazonia such as in South Peru and Ecuador, than the current Brazilian sites used in this study. 

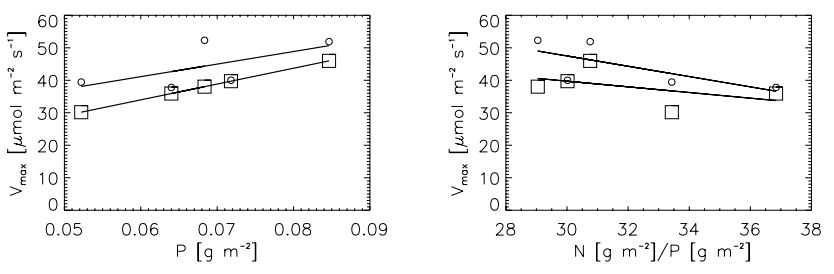

Fig. 7. Linear relationships obtained in this study (in circles) and obtained from tropical forest in Africa (in squares, Domingues, unpublished data).

\section{Summary}

Using a sun and shade model, the carbon uptake at 5 rainforest sites in the Brazilian Amazon was relatively well simulated. This result is supported by the ability of the model to reproduce values of $\delta^{13} \mathrm{C}$ discrimination, although this was obtained with a poor partition of energy at some sites, mainly for wet season measurements. Additionally, the sun and shade model coupled to a model for stomatal conductance based on that of Cowan and Farquhar (1977) was unable to accurately capture carbon and energy fluxes at high $D_{C}$, over predicting measurements. There is still a need to understand the physiology of the stomatal closure under the afternoon conditions in these forests before it can be modelled. Nevertheless, a stomatal conductance description including hydraulic supply and demand might improve the model response under such conditions (Buckley, 2005).

Major constraints to model-data evaluation exercises such as attempted here are, however, imposed by the uncertainty in estimates of ecosystem respiration, mainly due to the seasonality of soil respiration, but also $\mathrm{CO}_{2}$ storage fluxes and uncertainties associated with measurements from the eddy correlation $N_{E}$ and non-closure of the energy balance.

Finally we note that this modelling exercise can be used to extrapolate simulations to the basin level. We have developed empirical relations between best fits of $V_{\max }$ and foliar $\mathrm{N}$ and $\mathrm{P}$ concentrations that can be tested to scale up to the basin level. Furthermore, the relationship between of $V_{\max }$ and $\mathrm{P}$ suggests the possibility of foliar $\mathrm{P}$, or maybe N/P ratio a better predictor for canopy photosynthetic capacity than only foliar $\mathrm{N}$ in these forests. And given that most sites in western amazon have higher average foliar P (Fyllas et al., 2009), this might imply a gradient of GPP across Amazonia with higher GPP where leaf P is highest. Implications of these relationships will be explored further in an accompanying paper (Mercado et al., 2009) investigating the sensitivity of GPP to $V_{\max }$ parameterised using leaf $\mathrm{P}$ and leaf $\mathrm{N}$ at 35 sites across the Amazon Basin.

Results from this study highlight the need for field studies to further investigate the relationship between photosynthesis and leaf phosphorus in Amazonian forests.

\section{Appendix A}

\section{Equations for canopy photosynthesis using the sun and shade model from de Pury and Farquhar (1997)}

Following de Pury and Farquhar (1997), canopy level photosynthetic capacity is calculated as the integral of leaf photosynthetic capacity over the entire canopy, as parameterised with leaf level data for the Manaus Cl4 site in Mercado et al. (2006):

$$
\begin{aligned}
V_{\text {max _canopy }} & =\int_{0}^{\text {LAI }} V_{\text {max _leaf }} d l \\
V_{\text {max_canopy }} & =V_{\text {max _top }}\left[1-\exp \left(-k_{n}\right)\right] / k_{n}
\end{aligned}
$$

where $V_{\text {max _leaf }}$ is the maximum carboxylation activity of Rubisco at the leaf level in area basis, $V_{\max \_c a n o p y}$ is the canopy level value for $V_{\max }, V_{\max }$ top , is the $V_{\max }$ value for top leaves. The cumulative leaf area index from the top of the canopy down to any level in the canopy is $l$, LAI is the total canopy leaf area index and $k_{n}$ is a nitrogen or $V_{\max }$ allocation coefficient, defining the vertical decrease of $V_{\max }$ leaf with cumulative leaf area within the canopy.

Photosynthetic capacity of the sunlit and shaded fractions of the canopy is calculated by integrating the leaf photosynthetic capacity and the sunlit and shaded leaf area fractions, respectively. Photosynthesis of the sunlit and shaded fractions is then calculated separately using the leaf level biochemistry model of Farquhar and Caemmerer (1982), as two big leaves, with the absorbed irradiance and photosynthetic capacity, light saturated rate of electron transport and leaf dark respiration of each fraction used instead of the equivalent leaf level variables. Finally canopy photosynthesis is calculated by adding the individual contributions from the sunlit and shaded photosynthesis.

\section{A1 Leaf biochemistry}

The $\mathrm{CO}_{2}$ assimilation rate $(A)$ in units $\left(\mu \mathrm{mol} \mathrm{m} \mathrm{m}^{-1}\right)$ is controlled by the rate of carboxylation when Rubisco activity is limiting $\left(A_{v}\right)$ at low intercellular partial pressure of $\mathrm{CO}_{2}$ and/or at high irradiances, and by the rate of electron transfer when Ribulose bisphospate (RuBP) regeneration is limiting $\left(A_{J}\right)$ at high intercellular partial pressure of $\mathrm{CO}_{2}$ and/or at low irradiances. The rate of $\mathrm{CO}_{2}$ assimilation is modelled as the minimum of $A_{v}$ and $A_{J}$. The Rubisco-limited rate, $A_{v}$, and electron transport-limited rate, $A_{J}$, both in units

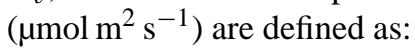

$$
\begin{aligned}
& A_{V}=V_{\max }\left(\frac{C_{c}-\Gamma^{*}}{K_{C}\left(1+p \mathrm{O}_{2} / K_{0}\right)+C_{c}}\right)-R_{C} \\
& A_{J}=\frac{J}{4}\left(\frac{C_{c}-\Gamma^{*}}{C_{c}+2 \Gamma^{*}}\right)-R_{C}
\end{aligned}
$$

where $V_{\max }$ in $\left(\mu \mathrm{mol} \mathrm{m} \mathrm{m}^{-1}\right)$ is the maximum rate of $\mathrm{Ru}$ bisco activity, $K_{0}$ and $K_{c}$ in (Pa) are the Michaelis-Menton 
constants for carboxylation and oxygenation by Rubisco. $C_{c}$ in $(\mathrm{Pa})$ is the partial pressure of $\mathrm{CO}_{2}$ in the chloroplast, $\Gamma^{*}$ in $(\mathrm{Pa})$ is the $\mathrm{CO}_{2}$ compensation point in the absence of mitochondrial respiration and $R_{C}$ in $\left(\mu \mathrm{mol} \mathrm{m} \mathrm{m}^{-1}\right)$ on a ground area basis, is the leaf dark respiration in the light. The Rubisco Michaelis constants for $\mathrm{CO}_{2}$ and $\mathrm{O}_{2}$ are described to follow an Arrhenius type temperature dependency as in Lloyd et al. (1995).

The potential rate of electron transport, $J$ in $\left(\mu \mathrm{mol} \mathrm{m} \mathrm{m}^{2} \mathrm{~s}^{-1}\right.$ ), is modelled as a non-rectangular hyperbolic function of the absorbed quantum flux with $I_{2}$ in ( $\mu$ mol quanta $\mathrm{m}^{2} \mathrm{~s}^{-1}$ ) the absorbed irradiance that reaches photosystem II, $J_{\max }$ in $\left(\mu \mathrm{mol} \mathrm{m} \mathrm{m}^{2} \mathrm{~s}^{-1}\right)$, as saturating value and $\theta$ as the curvature factor:

$$
\begin{aligned}
& \theta J^{2}-\left(I_{2}+J_{\max }\right) J+I_{2} J_{\max }=0 \\
& I_{2}=I_{0}(1-r-t)(1-f) \Phi
\end{aligned}
$$

$r$ and $t$ are the canopy reflectance and transmittance for PAR, respectively and $f$ is the fraction of light lost as absorption by other than chloroplast lamellae, wich increases with leaf thickness (Farquhar et al., 1980). $I_{0}$ is the PAR reaching the leaf or canopy surface in $\left(\mu \mathrm{mol}\right.$ quanta $\left.\mathrm{m}^{2} \mathrm{~s}^{-1}\right) . \Phi$ is the efficiency of $\mathrm{CO}_{2}$ fixation, so called quantum yield, defined as the initial slope of the relationship between assimilation rate $A$ and irradiance. It describes the efficiency with which light is converted into fixed carbon.

The temperature sensitivities for Rubisco activity and electron transport are given by Farquhar and von Caemmerer (1982) as presented by Lloyd et al. (1995):

$$
\begin{aligned}
& V_{\max }=V_{\max , 25} \exp \left(\frac{E_{v}}{298.2 R}\left(1-\frac{292.2}{T_{C}}\right)\right) \\
& J_{\max }=J_{\max , 25} \frac{\exp \left[\frac{\left(T_{C} / 298.2-1\right) E_{J}}{R T_{C}}\right]\left[1+\exp \left(\frac{298.2 S_{J}-H_{J}}{298.2 R}\right)\right]}{1+\exp \left(\frac{S_{J} T_{C}-H_{J}}{R T_{C}}\right)}
\end{aligned}
$$

where $T_{C}$ is absolute temperature $(\mathrm{K})$ of the leaf or canopy, $R$ is the universal gas constant $\left(8.314 \mathrm{~J} \mathrm{~mol}^{-1} \mathrm{~K}^{-1}\right), V_{\max , 25}$ and $J_{\max , 25}$ are Rubisco activity and electron transport capacity at $25^{\circ} \mathrm{C}$ in $\left(\mu \mathrm{mol}\right.$ quanta $\left.\mathrm{m}^{2} \mathrm{~s}^{-1}\right) . \quad E_{v}$ and $E_{J}$ in $\left(\mathrm{J} \mathrm{mol}^{-1}\right)$ are activation energies. $H_{J}$ in $\left(\mathrm{J} \mathrm{mol}^{-1}\right)$ and $S_{J}$ in $\left(\mathrm{J} \mathrm{mol}^{-1} \mathrm{~K}^{-1}\right)$ control maximum and minimum optimum temperature dependencies of the electron transport rate. The temperature optimum ( $T_{\text {opt }}$ ) of $J_{\max }$ is known to acclimate in different environments, and can be estimated from Farquhar et al. (1980):

$$
T_{\mathrm{opt}}=\frac{H_{J}}{\left(S+R \ln \left(H_{J} / E_{J}-1\right)\right)}
$$

The temperature dependency of leaf respiration is taken as presented by Lloyd et al. (1995):

$$
R_{D}=R_{D, 25} \exp \left(308.45\left(\frac{1}{71.02}-\frac{1}{T_{C}-227.13}\right)\right)
$$

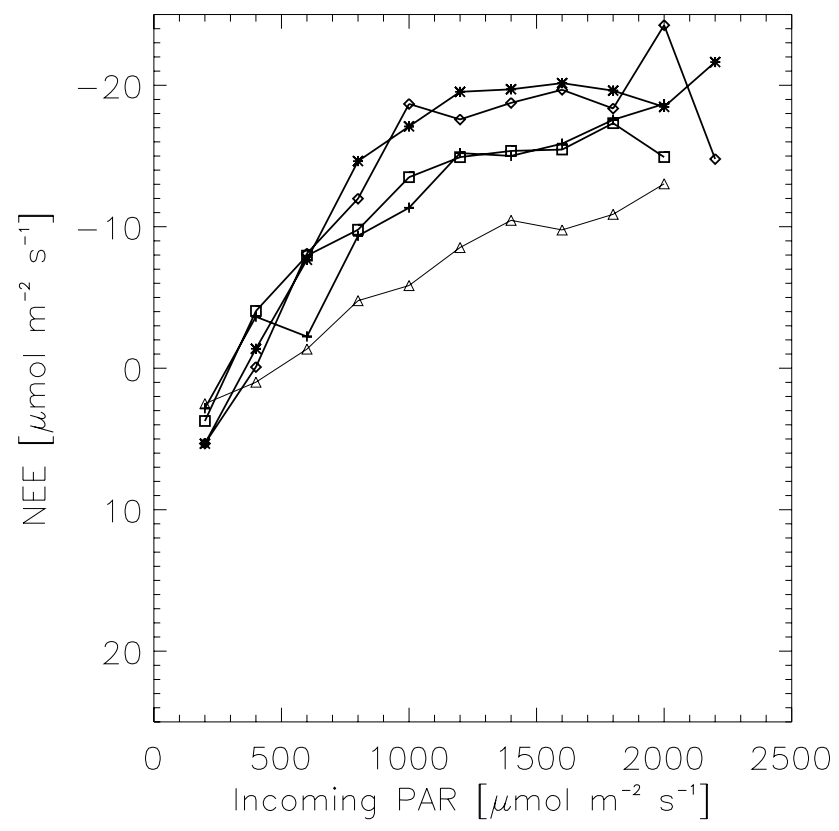

Fig. B1. Light response of $N_{E}$ measured by eddy correlation averaged over $200 \mu$ mol quanta $\mathrm{m}^{-2} \mathrm{~s}^{-1}$ bins at the different tower sites. Data used correspond to the period July-December. $\Delta$ Tapajos, $*$ Man K34, $\diamond$ Jaru, $\square$ Caxiuana, + Man C14.

where $R_{D}$ is the rate of canopy dark respiration at $T_{C}$ and $R_{D, 25}$ is the rate of canopy dark respiration at $25^{\circ} \mathrm{C}$, both are given in $\left(\mu \mathrm{mol} \mathrm{m} \mathrm{m}^{2} \mathrm{~s}^{-1}\right)$.

\section{A2 Stomatal conductance}

Stomatal conductance is calculated with the equation from Cowan and Farquhar (1977), called the "Lambda" model:

$G_{S}=A \sqrt{\frac{1.6 \lambda P}{\left(C_{a}-\Gamma^{*}\right) D c}}$

where $A$ is the $\mathrm{CO}_{2}$ assimilation rate in $\left(\mathrm{mol} \mathrm{m}^{-2} \mathrm{~s}^{-1}\right), D_{C}$ vapour pressure deficit in mol fraction, $P$ atmospheric pressure and $C_{a}$ ambient partial pressure of $\mathrm{CO}_{2}$, and $\Gamma^{*}$ is the $\mathrm{CO}_{2}$ compensation partial pressure in the absence of dark respiration, all expressed in $\left(\mathrm{mol} \mathrm{mol}^{-1}\right)$. The lambda parameter $(\lambda)$ in $\left(\mathrm{mol} \mathrm{H}_{2} \mathrm{O} \mathrm{mol}^{-1} \mathrm{CO}_{2}\right)$ is a Lagrangian multiplier representing the marginal water cost of plant carbon gain.

\section{Appendix B}

See the table and figures. 
Table B1. Calculated top of the canopy $V_{\max }$ in $\left(\mu \mathrm{mol} \mathrm{m} \mathrm{m}^{-2} \mathrm{~s}^{-1}\right)$ using linear regressions of $V_{\max }$ against foliar $\mathrm{N}$ from different sources and reported values of $V_{\max }$ from top canopy leaves.

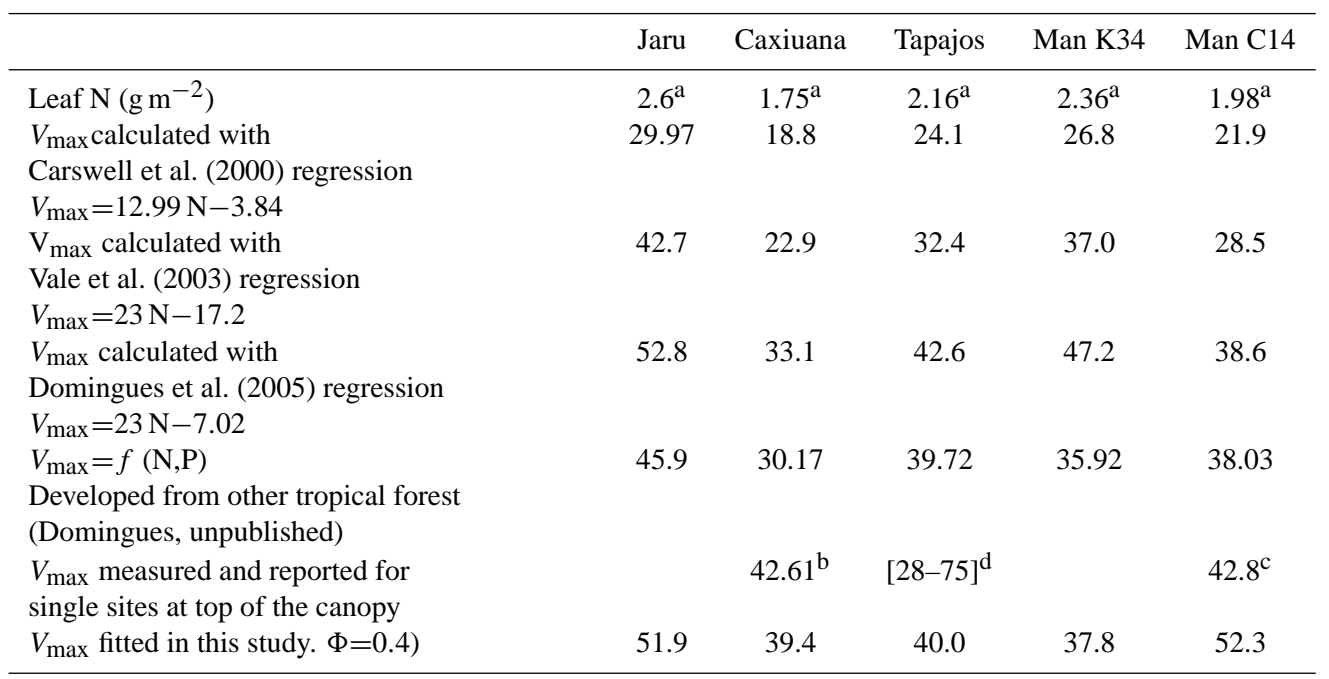

a Fyllas et al. (2009)

b Mean vaule at $30 \mathrm{~m}$ reported by Vale et al. (2003)

c Carswell et al. (2000) at $24 \mathrm{~m}$

${ }^{\mathrm{d}}$ Reported by Domingues et al. (2005) for top canopy leaves
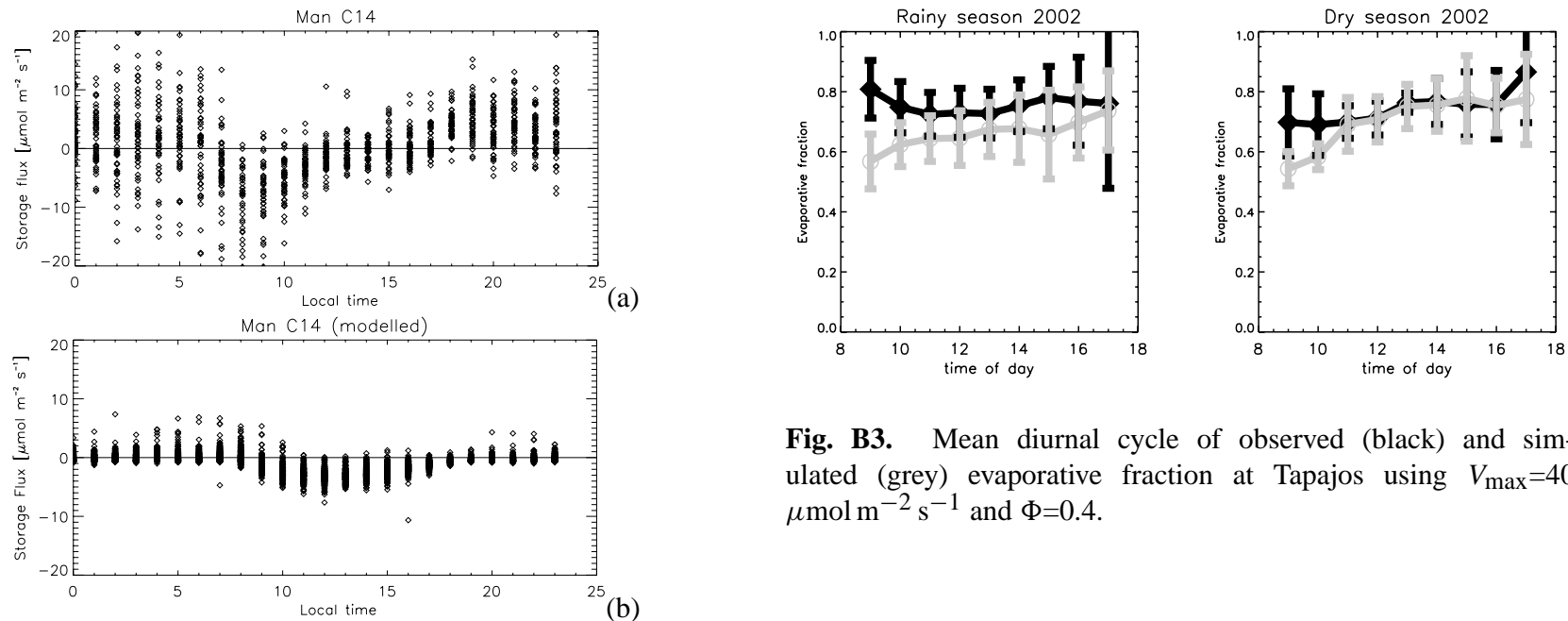

Fig. B3. Mean diurnal cycle of observed (black) and simulated (grey) evaporative fraction at Tapajos using $V_{\max }=40$ $\mu \mathrm{mol} \mathrm{m}^{-2} \mathrm{~s}^{-1}$ and $\Phi=0.4$.

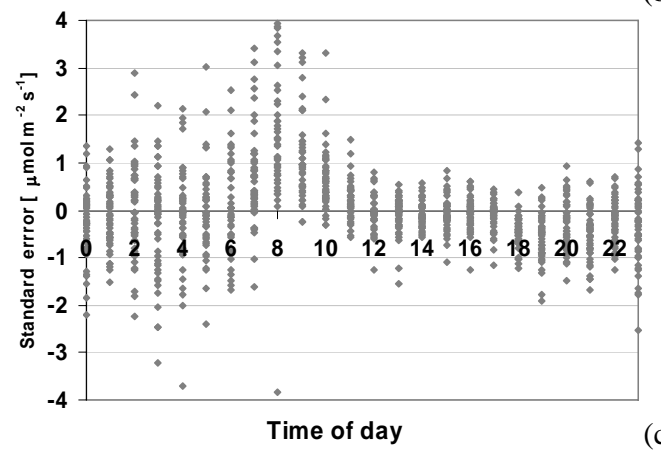

Acknowledgements. The authors wish to thank the following investigators for providing meteorology and eddy correlation flux data for the different sites: S. Saleska and N. Restrepo Coupe (University of Arizona), Tapajos site, A. Araujo (INPA), Manaus K34 site, C. von Randow (CPTEC/INPE) and B. Kruijt (Alterra), Jaru site, and A. Lola da Costa (Universidade Federal do Pará), Caxiuana and Y. Malhi (University of Oxford), Caxiuana site and Manaus $\mathrm{C} 14$ sites. We thank T. Domingues for supplying correlations of photosynthetic capacity and leaf nutrients in West Africa. Financial support for L. M. M. was provided through the EU Project "Carbonsink-LBA Proposal No. EVK 1999-0191" with most of this work being done at the Max-Planck-Institute for Biogeochemistry, Jena-Germany. The final analysis was also supported through salary support to L. M. M. through the UK National Environment Research Council funded Tropical Biomes in Transition (TROBIT) project. S. S. was supported by the

Fig. B2. (a) Observed and (b) simulated storage flux at Man C14 during the period October-November 1995. (c) Standardised residuals of observed and simulated storage flux at Man C14. 
DEFRA and MoD integrated Climate Programme - GA01101, BC/2B/0417_Annex C5.r.

The service charges for this open access publication have been covered by the Max Planck Society.

Edited by: J. Grace

\section{References}

Aranibar, J. N., Berry, J. A., Riley, W. J., Pataki, D. E., Law, B. E., and Ehleringer, J. R.: Combining meteorology, eddy fluxes, isotope measurements, and modeling to understand environmental controls of carbon isotope discrimination at the canopy scale, Glob. Change Biol., 12, 710-730, 2006.

Araújo, A. C., Nobre, A. D., Kruijt, B., Elbers, J. A., Dallarosa, R., Stefani, P., von Randow, C., Manzi, A. O., Culf, A. D., Gash, J. H. C., Valentini, R., and Kabat, P.: Comparative measurements of carbon dioxide fluxes from two nearby towers in a central Amazonian rainforest: The Manaus LBA site, J. Geophys. Res. Atmos., 107, 8090, doi:10.1029/2001JD000676, 2002.

Asner, G. P., Nepstad, D., Cardinot, G., and Ray, D.: Drought stress and carbon uptake in an Amazon forest measured with spaceborne imaging spectroscopy, Proc. Natl. Acad. Sci. USA, 101, 6039-6044, 2004.

Atkin, O. K., Evans, J. R., and Siebke, K.: Relationship between the inhibition of leaf respiration by light and enhancement of leaf dark respiration following light treatment, Aust. J. Plant Physiol., 25, 437-443, 1998.

Atkin, O. K., Evans, J. R., Ball, M. C., Lambers, H., and Pons, T. L.: Leaf respiration of snow gum in the light and dark. interactions between temperature and irradiance, Plant Physiol., 122, 915923, 2000.

Aubinet, M., Heinesch, B., and Longdoz, B.: Estimation of the carbon sequestration by a heterogeneous forest: night flux corrections, heterogeneity of the site and inter-annual variability, Glob. Change Biol., 8, 1053-1071, 2002.

Baker, T. R., Phillips, O. L., Malhi, Y., Almeida, S., Arroyo, L., Di Fiore, A., Erwin, T., Higuchi, N., Killeen, T. J., Laurance, S. G., Laurance, W. F., Lewis, S. L., Monteagudo, A., Neill, D. A., Vargas, P. N., Pitman, N. C. A., Silva, J. N. M., and Martinez, R. V.: Increasing biomass in Amazonian forest plots, Philos. Trans. R. Soc. Lond. Ser. B-Biol. Sci., 359, 353-365, 2004.

Baldocchi, D. D.: Assessing the eddy covariance technique for evaluating carbon dioxide exchange rates of ecosystems: past, present and future, Glob. Change Biol., 9, 479-492, 2003.

Ball, J. T., Woodrow, I. E., and Berry, J. A.: A model predicting stomatal conductance and its contribution to the control of photosynthesis under different environmental conditions, in: Progress in Photosynthesis Research, edited by: Martinus Nijhoff, M. J. B., Dordrecht, 221-224, 1987.

Brooks, A. and Farquhar, G. D.: Effect of temperature on the $\mathrm{CO}_{2} / \mathrm{O}_{2}$ specificity of ribulose 1,5-bisphosphate carboxylase oxygenase and the rate of respiration in the light: estimates from gas exchange measurements on spinach, Planta, 165, 397-406, 1985.

Brooks, A.: Effects of Phosphorus-Nutrition on Ribulose-1,5Bisphosphate Carboxylase Activation, Photosynthetic Quan- tum Yield and Amounts of Some Calvin-Cycle Metabolites in Spinach Leaves, Aust. J. Plant Physiol., 13, 221-237, 1986.

Brooks, A., Woo, K. C., and Wong, S. C.: Effects of PhosphorusNutrition on the Response of Photosynthesis to $\mathrm{CO}_{2}$ and $\mathrm{O}_{2}$, Activation of Ribulose Bisphosphate Carboxylase and Amounts of Ribulose Bisphosphate and 3-Phosphoglycerate in Spinach Leaves, Photosynth. Res., 15, 133-141, 1988.

Buckley, T. N.: The control of stomata by water balance, New Phytol., 168, 275-291, doi:10.1111/j.1469-8137.2005.01543.x, 2005.

Campbell, C. D. and Sage, R. F.: Interactions between the effects of atmospheric $\mathrm{CO}_{2}$ content and $\mathrm{P}$ nutrition on photosynthesis in white lupin (Lupinus albus L.), Plant Cell Environ., 29, 844-853, doi:10.1111/j.1365-3040.2005.01464.x, 2006.

Carswell, F. E., Meir, P., Wandelli, E. V., Bonates, L. C. M., Kruijt, B., Barbosa, E. M., Nobre, A. D., Grace, J., and Jarvis, P. G.: Photosynthetic capacity in a central Amazonian rain forest, Tree Physiol., 20, 179-186, 2000.

Carswell, F. E., Costa, A. L., Palheta, M., Malhi, Y., Meir, P., Costa, J. D. R., Ruivo, M. D., Leal, L. D. M., Costa, J. M. N., Clement, R. J., and Grace, J.: Seasonality in $\mathrm{CO}_{2}$ and $\mathrm{H}_{2} \mathrm{O}$ flux at an eastern Amazonian rain forest, J. Geophys. Res. Atmos., 107(D20), 8076, doi:10.1029/2000JD000284, 2002.

Chambers, J. Q., Higuchi, N., Schimel, J. P., Ferreira, L. V., and Melack, J. M.: Decomposition and carbon cycling of dead trees in tropical forests of the central Amazon, Oecologia, 122, 380388, 2000.

Chambers, J., Tribuzy, E. S., Toledo, L. C., Crispim, B. F., Higuchi, N., dos Santos, J., Araujo, A. C., Kruijt, B., Nobre, A., and Trumbore, S.: Respiration from a tropical forest ecosystem: partitioning of sources and low carbon use efficiency, Ecol. Appl., 14, S72-S88, 2004.

Chambers, J. Q. and Silver, W. L.: Some aspects of ecophysiological and biogeochemical responses of tropical forests to atmospheric change, Philos. T. Roy. Soc. B, 359, 463-476, 2004.

Collatz, G. J., Berry, J. A., Farquhar, G., and Pierce, J.: The relationship between the Rubisco reaction mechanism and models of photosynthesis, Plant Cell Environ., 13, 219-225, 1990.

Collatz, G. J., Ball, J. T., Grivet, C., and Berry, J. A.: Physiological and environmental regulation of stomatal conductance, photosynthesis and transpiration: a model that includes a laminar boundary layer, Agr. Forest Meteorol., 54, 107-136, 1991.

Cowan, I. R. and Farquhar, G. D.: Stomatal function in relation to leaf metabolism and environment, Symposium of the Society for Experimental Biology, 471-505, 1977.

Cox, P. M., Betts, R. A., Jones, C. D., Spall, S. A., and Totterdell, I. J.: Acceleration of global warming due to carbon-cycle feedbacks in a coupled climate model, Nature, 408, 750-750, 2000.

da Rocha, H. R., Goulden, M. L., Miller, S. D., Menton, M. C., Pinto, L., de Freitas, H. C., and Figueira, A.: Seasonality of water and heat fluxes over a tropical forest in eastern Amazonia, Ecol. Appl., 14, S22-S32, 2004.

Davidson, E. A., Verchot, L. V., Cattanio, J. H., Ackerman, I. L., and Carvalho, J. E. M.: Effects of soil water content on soil respiration in forests and cattle pastures of eastern Amazonia, Biogeochemistry, 48, 53-69, 2000.

de Pury, D. G. G. and Farquhar, G. D.: Simple scaling of photosynthesis from leaves to canopies without the errors of big-leaf 
models, Plant Cell Environ., 20, 537-557, 1997.

Domingues, T. F., Berry, J. A., Martinelli, L. A., Ometto, J. P. H. B., and Ehleringer, J. R.: Parameterization of canopy structure and leaf-level gas exchange for an Eastern Amazonian Tropical Rain Forest (Tapajos National Forest, Para, Brazil), Earth Interact., 9, 1-23, 2005.

Doughty, C. E. and Goulden, M. L.: Seasonal patterns of tropical forest leaf area index and $\mathrm{CO}_{2}$ exchange, J. Geophys. Res.Biogeosci., 113, G00b06, doi:10.1029/2007jg000590, 2008a.

Doughty, C. E. and Goulden, M. L.: Are tropical forests near a high temperature threshold?, J. Geophys. Res.-Biogeosci., 113, G00b07, doi:10.1029/2007jg000632, 2008b.

Ehleringer, J. and Björkman, O.: Quantum Yields for $\mathrm{CO}_{2}$ Uptake in $\mathrm{C} 3$ and C4 Plants: Dependence on Temperature, $\mathrm{CO}_{2}$, and $\mathrm{O}_{2}$ Concentration, Plant Physiol., 59, 86-90, 1977.

Ehleringer, J. and Pearcy, R. W.: Variation in Quantum Yield for $\mathrm{CO}_{2}$ Uptake among $\mathrm{C} 3$ and $\mathrm{C} 4$ plants, Plant Physiol., 73, 555$559,1983$.

Ehleringer, J. R., Lin, Z. F., Field, C. B., Sun, G. C., and Kuo, C. Y.: Leaf carbon isotope ratios of plants from a subtropical monsoon forest, Oecologia, 72, 109-114, 1987.

Evans, J. R.: Photosynthetic Acclimation and Nitrogen Partitioning within a Lucerne Canopy 1. Canopy Characteristics, Aust. J. Plant Physiol., 20, 55-67, 1993.

Farquhar, G. D., Caemmerer, S. V., and Berry, J. A.: A Biochemical-Model of Photosynthetic $\mathrm{CO}_{2}$ Assimilation in Leaves of C-3 Species, Planta, 149, 78-90, 1980.

Farquhar, G. D., Oleary, M. H., and Berry, J. A.: On the Relationship between Carbon Isotope Discrimination and the InterCellular Carbon-Dioxide Concentration in Leaves, Aust. J. Plant Physiol., 9, 121-137, 1982.

Farquhar, G. D. and von Caemmerer, S.: Modelling of photosynthetic response to environmental conditions, in: Enciclopedia of Plant physiology, edited by: Lange, O. L., Nobel, P. S., Osmond, C. B., and Ziegler, H., Springer-Verlag, Berlin, 549-587, 1982.

Finnigan, J. J., Clement, R., Malhi, Y., Leuning, R., and Cleugh, H. A.: A re-evaluation of long-term flux measurement techniques - Part I: Averaging and coordinate rotation, Bound.Lay. Meteorol., 107, 1-48, 2003.

Fisher, R. A., Williams, M., Da Costa, A. L., Malhi, Y., Da Costa, R. F., Almeida, S., and Meir, P.: The response of an Eastern Amazonian rain forest to drought stress: results and modelling analyses from a throughfall exclusion experiment, Glob. Change Biol., 13, 2361-2378, 2007.

Fyllas, N. M., Patiño, S., Baker, T. R., Bielefeld Nardoto, G., Martinelli, L. A., Quesada, C. A., Paiva, R., Schwarz, M., Horna, V., Mercado, L. M., Santos, A., Arroyo, L., Jiménez, E. M., Luizão, F. J., Neill, D. A., Silva, N., Prieto, A., Rudas, A., Silviera, M., Vieira, I. C. G., Lopez-Gonzalez, G., Malhi, Y., Phillips, O. L., and Lloyd, J.: Basin-wide variations in foliar properties of Amazonian forest: phylogeny, soils and climate, Biogeosciences Discuss., 6, 3707-3769, 2009,

http://www.biogeosciences-discuss.net/6/3707/2009/.

Gash, J. H. C. and Dolman, A. J.: Sonic anemometer (co)sine response and flux measurement I. The potential for (co)sine error to affect sonic anemometer-based flux measurements, Agr. Forest Meteorol., 119, 195-207, 2003.

Goudriaan, J.: Crop micrometeorology: A simulation study, Cen- tre for Agricultural Publishing and Documentation, Wageningen, The Netherlands, 249 pp., 1977.

Goulden, M. L., Miller, S. D., da Rocha, H. R., Menton, M. C., de Freitas, H. C., Figueira, A., and de Sousa, C. A. D.: Diel and seasonal patterns of tropical forest $\mathrm{CO}_{2}$ exchange, Ecol. Appl., 14, S42-S54, 2004.

Grace, J., Lloyd, J., McIntyre, J., Miranda, A. C., Meir, P., Miranda, H. S., Nobre, C., Moncrieff, J., Massheder, J., Malhi, Y., Wright, I., and Gash, J.: Carbon-dioxide uptake by an undisturbed tropical rain-forest in Southwest Amazonia, 1992 to 1993, Science, 270, 778-780, 1995a.

Grace, J., Lloyd, J., McIntyre, J., Miranda, A., Meir, P., Miranda, H., Moncrieff, J., Massheder, J., Wright, I., and Gash, J.: Fluxes of carbon-dioxide and water-vapor over an undisturbed tropical forest in South-West Amazonia, Glob. Change Biol., 1, $1-12,1995 b$.

Grace, J., Mahli, Y., Higuchi, N., and Meir, P.: Productivity and carbon fluxes of tropical rain forest, in: Global Terrestrial Productivity: Past, Present and Future, edited by: Mooney, H. and Saugier, B., Academic Press, San Diego, 401-426, 2001.

Harley, P. C. and Sharkey, T. D.: An Improved Model of $\mathrm{C}_{3}$ Photosynthesis at High $\mathrm{CO}_{2}-$ Reversed $\mathrm{O}_{2}$ Sensitivity Explained by Lack of Glycerate Reentry into the Chloroplast, Photosynth. Res., 27, 169-178, 1991.

Harley, P. C., Thomas, R. B., Reynolds, J. F., and Strain, B. R.: Modeling Photosynthesis of Cotton Grown in Elevated $\mathrm{CO}_{2}$, Plant Cell Environ., 15, 271-282, 1992.

Hirose, T. and Werger, M. J. A.: Maximizing daily canopy photosynthesis with respect to the leaf nitrogen allocation pattern in the canopy, Oecologia, 72, 520-526, 1987.

Hoefnagel, M. H. N., Atkin, O. K., and Wiskich, J. T.: Interdependence between chloroplasts and mitochondria in the light and the dark, BBA-Bioenergetics, 1366, 235-255, 1998.

Hutyra, L. R., Munger, J. W., Hammond-Pyle, E., Saleska, S. R., Restrepo-Coupe, N., de Camargo, P. B., and Wofsy, S. C.: Resolving systematic errors in estimates of net ecosystem exchange of $\mathrm{CO}_{2}$ and ecosystem respiration in a tall-stature forest: application to a tropical forest biome, Agr. Forest Meteorol., 148, 12661279, doi:10.1016/j.agrformet.2008.08.03, 2007.

Iwata, H., Malhi, Y., and von Randow, C.: Gap-filling measurements of carbon dioxide storage in tropical rainforest canopy airspace, Agr. Forest Meteorol., 132, 305-314, doi:10.1016/j.agrformet.2005.08.005, 2005.

Jacob, J. and Lawlor, D. W.: Dependence of Photosynthesis of Sunflower and Maize leaves on phosphate supply, ribulose-1,5bisphosphate carboxylase/oxygenase activity, and ribulose-1,5bisphosphate pool size, Plant Physiol., 98, 801-807, 1992.

Janssens, I. A., Lankreijer, H., Matteucci, G., Kowalski, A. S., Buchmann, N., Epron, D., Pilegaard, K., Kutsch, W., Longdoz, B., Grunwald, T., Montagnani, L., Dore, S., Rebmann, C., Moors, E. J., Grelle, A., Rannik, U., Morgenstern, K., Oltchev, S., Clement, R., Gudmundsson, J., Minerbi, S., Berbigier, P., Ibrom, A., Moncrieff, J., Aubinet, M., Bernhofer, C., Jensen, N. O., Vesala, T., Granier, A., Schulze, E.-D., Lindroth, A., Dolman, A. J., Jarvis, P. G., Ceulemans, R., and Valentini, R.: Productivity overshadows temperature in determining soil and ecosystem respiration across European forests, Glob. Change Biol., 7, 269-278, 2001.

Jones, H. G.: Plants and Microclimate, 2nd edn., Cambridge Uni- 
versity Press, Cambridge, 1992.

Katul, G. G., Ellsworth, D. S., and Lai, C.-T.: Modelling assimilation and intercellular $\mathrm{CO}_{2}$ from measured conductance: a synthesis of approaches, Plant Cell Environ., 23, 1313-1328, 2000.

Keeling, H. C. and Phillips, O. L.: A calibration method for the crown illumination index for assessing forest light environments, Forest Ecol. Manag., 242, 431-437, doi:10.1016/j.foreco.2007.01.060, 2007.

Klinge, H.: Litter production in an area of Amazonian Terra firme forest. Part I. Litter-fall, organic carbon and total nitrogen contents of litter, Amazoniana, 1, 287-302, 1968.

Kruijt, B., Elbers, J. A., von Randow, C., Araujo, A. C., Oliveira, P. J., Culf, A., Manzi, A. O., Nobre, A. D., Kabat, P., and Moors, E. J.: The robustness of eddy correlation fluxes for Amazon rain forest conditions, Ecol. Appl., 14, S101-S113, 2004.

Leuning, R.: Modeling stomatal behavior and photosynthesis of Eucalyptus grandis, Aust. J. Plant Physiol., 17, 159-175, 1990.

Leuning, R.: A Critical-Appraisal of a Combined StomatalPhotosynthesis Model for C-3 Plants, Plant Cell Environ., 18, 339-355, 1995.

Leuning, R., Kelliher, F. M., Depury, D. G. G., and Schulze, E. D.: Leaf nitrogen, photosynthesis, conductance and transpiration: scaling from leaves to canopies, Plant Cell Environ., 18, 11831200, 1995.

Lewis, S. L., Malhi, Y., and Phillips, O. L.: Fingerprinting the impacts of global change on tropical forests, Philos. T. Roy. Soc. B, 359, 437-462, 2004.

Lloyd, J. and Farquhar, G. D.: C-13 Discrimination during $\mathrm{CO}_{2}$ assimilation by the terrestrial biosphere, Oecologia, 99, 201-215, 1994.

Lloyd, J. and Taylor, J. A.: On the temperature dependence of soil respiration, Funct. Ecol., 8, 315-323, 1994.

Lloyd, J., Grace, J., Miranda, A. C., Meir, P., Wong, S. C., Miranda, B. S., Wright, I. R., Gash, J. H. C., and McIntyre, J.: A Simple Calibrated Model of Amazon Rain-Forest Productivity Based on Leaf Biochemical-Properties, Plant Cell Environ., 18, 1129-1145, 1995.

Lloyd, J. and Farquhar, G. D.: The $\mathrm{CO}_{2}$ dependence of photosynthesis, plant growth responses to elevated atmospheric $\mathrm{CO}_{2}$ concentrations and their interaction with soil nutrient status 1 . General principles and forest ecosystems, Funct. Ecol., 10, 4-32, 1996.

Lloyd, J., Kruijt, B., Hollinger, D., Grace, J., Francey, R. J., Wong, S. C., Kelliher, F. M.,Miranda, A. C., Farquhar, G. D., Gash, J. H. C., Vygodskaya, N. N., Wright, I. R., Miranda, H. S., and Schulze, E. D.: Vegetation effects on the isotopic composition of the atmospheric $\mathrm{CO}_{2}$ at local and regional scales: Theoretical aspects and a comparison between rain forest in amazonia and a boreal forest in Siberia, Aust. J. Plant Physiol., 23, 371399, 1996.

Lloyd, J., Bird, M. I., Veenendaal, E. M., and Kruijt, B.: Should Phosphorous Availability be Constraining Moist Tropical Forest responses to incrasing $\mathrm{CO}_{2}$ concentrations?, in: Global biogeochemical cycles in the climate system, edited by: Schulze, E. D., Schimel, D. S., Heimann, M., Harrison, S. P., Holland, E. A., Lloyd, J., and Prentice, I. C., Academic Press, San Diego, 95114, 2001.

Lloyd, J. and Farquhar, G. D.: Effects of rising temperatures and
$\left[\mathrm{CO}_{2}\right]$ on the physiology of tropical forest trees, Philos. T. Roy. Soc. B, 363, 1811-1817, doi:10.1098/rstb.2007.0032, 2008.

Lloyd, J., Patiño, S., Paiva, R. Q., Nardoto, G. B., Quesada, C. A., Santos, A. J. B., Baker, T. R., Brand, W. A., Hilke, I., Gielmann, H., Raessler, M., Luizao, F. J., Martinelli, L. A., and Mercaco, L. M.: Gradients in leaf physiological properties within Amazon forest canopies, Biogeosciences Discuss., in preparation, 2009.

Long, S. P., Postl, W. F., and Bolharnordenkampf, H. R.: Quantum Yields for Uptake of Carbon-Dioxide in C-3 Vascular Plants of Contrasting Habitats and Taxonomic Groupings, Planta, 189, 226-234, 1993.

Luizao, F. and Schubart, H. O. R.: Litter production and decomposition in a terra-firme forest of Central Amazonia, Experientia, 43, 259-265, 1987.

Malhi, Y., Nobre, A. D., Grace, J., Kruijt, B., Pereira, M. G. P., Culf, A., and Scott, S.: Carbon dioxide transfer over a Central Amazonian rain forest, J. Geophys. Res. Atmos., 103, 3159331612, 1998.

Malhi, Y., Pegoraro, E., Nobre, A. D., Pereira, M. G. P., Grace, J., Culf, A. D., and Clement, R.: Energy and water dynamics of a central Amazonian rain forest, J. Geophys. Res. Atmos., 107, 8061, doi:10.1029/2001JD000623, 2002.

Massman, W. J. and Lee, X.: Eddy covariance flux corrections and uncertainties in long-term studies of carbon and energy exchanges, Agr. Forest Meteorol., 113, 121-144, 2002.

Medlyn, B. E., Dreyer, E., Ellsworth, D., Forstreuter, M., Harley, P. C., Kirschbaum, M. U. F., Le Roux, X., Montpied, P., Strassemeyer, J., Walcroft, A., Wang, K., and Loustau, D.: Temperature response of parameters of a biochemically based model of photosynthesis. II. A review of experimental data, Plant Cell Environ., 25, 1167-1179, doi:10.1046/j.13653040.2002.00891.x, 2002.

Meir, P., Grace, J., Miranda, A. C., and Lloyd, J.: Soil Respiration in a rainforest in Amazonia and in cerrado in central Brazil, in: Amazon Deforestation and Climate, edited by: Gash, J. H. C., Nobre, C. A., Roberts, J., and Victoria, R. L., John Wiley \& Sons, Chichester, UK, 319-329, 1996.

Meir, P., Grace, J., and Miranda, A. C.: Photographic method to measure the vertical distribution of leaf area density in forests, Agr. Forest Meteorol., 102, 105-111, 2000.

Meir, P., Grace, J., and Miranda, A. C.: Leaf respiration in two tropical rainforests: constraints on physiology by phosphorus, nitrogen and temperature, Funct. Ecol., 15, 378-387, 2001.

Meir, P. and Grace, J.: Scaling relationships for woody tissue respiration in two tropical rain forests, Plant Cell Environ., 25, 963973, 2002.

Meir, P., Metcalfe, D. B., Costa, A. C. L., and Fisher, R. A.: The fate of assimilated carbon during drought: impacts on respiration in Amazon rainforests, Philos. T. Roy. Soc. B, 363, 1849-1855, doi:10.1098/rstb.2007.0021, 2008.

Mercado, L. M., Lloyd, J., Carswell, F., Mahli, Y., Meir, P., and Nobre, A.: Modelling Amazonian forest eddy covariance data: a comparison of big leaf versus sun/shade model fors the C-14 tower at Manaus I. Canopy photosynthesis, Acta Amazonica, 36, 69-82, 2006.

Mercado, L. M.: Modelling Rainforest Caonpy Photosynthesis across the Amazon Basin, Ph.D. thesis, Free University of Amsterdam, Amsterdam, 2007. 
Mercado, L. M., Lloyd, J., Dolman, A. J., Sitch, S., and Patiño, S.: Modelling basin-wide variations in Amazon forest productivity - Part 2: Application of the model on a Basin-wide scale, in preparation, 2009.

Mercado, L. M., Huntingford, C., Gash, J. H. C., Cox, P. M., and Jogireddy, V.: Improving the representation of radiation interception and photosynthesis for climate model applications, Tellus B, 59, 553-565, 2007.

Miller, S. D., Goulden, M. L., Menton, M. C., da Rocha, H. R., de Freitas, H. C., Figueira, A., and de Sousa, C. A. D.: Biometric and micrometeorological measurements of tropical forest carbon balance, Ecol. Appl., 14, S114-S126, 2004.

Morales, P., Sykes, M. T., Prentice, I. C., Smith, P., Smith, B., Bugmann, H., Zierl, B., Friedlingstein, P., Viovy, N., Sabate, S., Sanchez, A., Pla, E., Gracia, C. A., Sitch, S., Arneth, A., and Ogee, J.: Comparing and evaluating process-based ecosystem model predictions of carbon and water fluxes in major European forest biomes, Glob. Change Biol., 11, 2211-2233, 2005.

Nelder, J. A. and Mead, R.: A Simplex-Method for Function Minimization, Comput. J., 7, 308-313, 1965.

Nepstad, D. C., Moutinho, P., Dias, M. B., Davidson, E., Cardinot, G., Markewitz, D., Figueiredo, R., Vianna, N., Chambers, J., Ray, D., Guerreiros, J. B., Lefebvre, P., Sternberg, L., Moreira, M., Barros, L., Ishida, F. Y., Tohlver, I., Belk, E., Kalif, K., and Schwalbe, K.: The effects of partial throughfall exclusion on canopy processes, aboveground production, and biogeochemistry of an Amazon forest, J. Geophys. Res. Atmos., 107, 8085, doi:10.1029/2001JD000360, 2002.

Ometto, J. P. H. B., Ehleringer, J. H., Domingues, T. F., Berry, J. A., Ishida, F. Y., Mazzi, E., Higuchi, N., Flanagan, L., Nardoto, G. B., and Martinelli, L. A.: The stable carbon and nitrogen isotopic composition of vegetation in tropical forests of the Amazon region, Brazil, Biogeochemistry, 79, 251-274, 2006.

Pattey, E., Strachan, I. B., Desjardins, R. L., and Massheder, J.: Measuring nighttime $\mathrm{CO}_{2}$ flux over terrestrial ecosystems using eddy covariance and nocturnal boundary layer methods, Agr. Forest Meteorol., 113, 145-158, 2002.

Phillips, O. L., Malhi, Y., Higuchi, N., Laurance, W. F., Nunez, P. V., Vasquez, R. M., Laurance, S. G., Ferreira, L. V., Stern, M., Brown, S., and Grace, J.: Changes in the carbon balance of tropical forests: Evidence from long-term plots, Science, 282, 439$442,1998$.

Poorter, L., Oberbauer, S. F., and Clark, D. B.: Leaf opticalproperties along a vertical gradient in a tropical rain-forest canopy in Costa-Rica, Am. J. Bot., 82, 1257-1263, 1995.

Prentice, I. C. and Lloyd, J.: C-quest in the Amazon Basin, Nature, 396, 619-620, 1998.

Quesada, C. A., Lloyd, J., Anderson, L. O., Fyllas, N. M., Schwarz, M., and Czimczik, C. I.: Soils of amazonia with particular reference to the rainfor sites, Biogeosciences Discuss., 6, 3851-3921, 2009, http://www.biogeosciences-discuss.net/6/3851/2009/.

Restrepo-Coupe, N., da Rocha, H., Saleska, S. R., Aguiar, R. G., Araujo, A. C, Borma L. S., Cabral, O. M. R., de Camargo, P. B.,Cardoso, F. L., da Costa, L. A. C., Fitzjarrald, D. R., Goulden, M. L., Hutyra, L. R., Kruijt, B., Maia, J. M. F, Malhi, Y., Manzi, A. O., Miller, S. D., Nobre, A. D., von Randow, C., da Abreu Sá, L. D., Sakai, R. K., Tota, J., Wofsy, S. C., and Zanchi, F. B.: What controls the seasonality of photosynthesis across the Amazon basin? A cross-site analysis of eddy flux tower measurements from the Brasil flux network, in preparation, 2009.

Sage, R. F. and Kubien, D. S.: The temperature response of C3 and C-4 photosynthesis, Plant Cell Environ., 30, 1086-1106, 10.1111/j.1365-3040.2007.01682.x, 2007.

Saleska, S. R., Miller, S. D., Matross, D. M., Goulden, M. L., Wofsy, S. C., da Rocha, H. R., de Camargo, P. B., Crill, P., Daube, B. C., de Freitas, H. C., Hutyra, L., Keller, M., Kirchhoff, V., Menton, M., Munger, J. W., Pyle, E. H., Rice, A. H., and Silva, H.: Carbon in amazon forests: Unexpected seasonal fluxes and disturbance-induced losses, Science, 302, 1554-1557, 2003.

Sharkey, T. D.: $\mathrm{O}_{2}$-insensitive photosynthesis in C3 plants: Its occurrence and a possible explanation, Plant Physiol., 78, 71-75, 1985.

Shuttleworth, W. J.: Micrometeorology of temperate and tropical forest, Philos. T. Roy. Soc. B, 324, 299-334, 1989.

Silva de Souza, J.: Dinamica espacial e temporal do fluxo de $\mathrm{CO}_{2}$ do solo em floresta de terra firme na amazonia central, Master thesis, Universidad Federal do Amazonas, Manaus, 2004.

Simon, E., Meixner, F. X., Ganzeveld, L., and Kesselmeier, J.: Coupled carbon-water exchange of the Amazon rain forest, I. Model description, parameterization and sensitivity analysis, Biogeosciences, 2, 231-253, 2005, http://www.biogeosciences.net/2/231/2005/.

Sitch, S., Smith, B., Prentice, I. C., Arneth, A., Bondeau, A., Cramer, W., Kaplan, J. O., Levis, S., Lucht, W., Sykes, M. T., Thonicke, K., and Venevsky, S.: Evaluation of ecosystem dynamics, plant geography and terrestrial carbon cycling in the LPJ dynamic global vegetation model, Glob. Change Biol., 9, 161$185,2003$.

Sotta, E. D., Meir, P., Malhi, Y., Nobre, A. D., Hodnett, M., and Grace, J.: Soil $\mathrm{CO}_{2}$ efflux in a tropical forest in the central Amazon, Glob. Change Biol., 10, 601-617, 2004.

Terry, N. and Ulrich, A.: Effects of phosphorus deficiency on the photosynthesis and respiration of leaves of sugar beet, Plant Physiol., 51, 43-47, 1973.

Thornley, J. H. M.: Instantaneous canopy photosynthesis: Analytical expressions for sun and shade leaves based on exponential light decay down the canopy and an acclimated non-rectangular hyperbola for leaf photosynthesis, Ann. Bot., 89, 451-458, 2002.

Tian, H. Q., Melillo, J. M., Kicklighter, D. W., McGuire, A. D., Helfrich III, J. V. K., Moore III, B., and Vörösmarty, C. J.: Effect of interannual climate variability on carbon storage in Amazonian ecosystems, Nature, 396, 664-667, 1998.

Tuzet, A., Perrier, A., and Leuning, R.: A coupled model of stomatal conductance, photosynthesis and transpiration, Plant Cell Environ., 26, 1097-1116, doi:10.1046/j.13653040.2003.01035.x, 2003.

Tyree, M. T.: Hydraulic limits on tree performance: transpiration, carbon gain and growth of trees, Trees-Struct. Funct., 17, 95100, 2003.

Vale, R. L., Maroco, J. P., Carvalho, C. R. J., Almeida, S., Meir, P., Grace, J., Pereira, J. S., and Chaves, M. M.: Carbon assimilation in an amazonian rainforest: a rain exclusion experiment, in: Comparative Bioqchemistry and Physiology, Abstracts of the Annual Main Meeting of the Society for Experimental Biology, Southampton, UK, S1-S238, 2003.

van der Molen, M. K., Gash, J. H. C., and Elbers, J. A.: Sonic 
anemometer (co)sine response and flux measurement - II. The effect of introducing an angle of attack dependent calibration, Agr. Forest Meteorol., 122, 95-109, 2004.

van Gorsel, E., Leuning, R., Cleugh, H. A., Keith, H., and Suni, T.: Nocturnal carbon efflux: reconciliation of eddy covariance and chamber measurements using an alternative to the $\mathrm{u}(*)$-threshold filtering technique, Tellus B, 59, 397-403, 2007.

van Gorsel, E., Leuning, R., Cleugh, H. A., Keith, H., Kirschbaum, M. U. F., and Suni, T.: Application of an alternative method to derive reliable estimates of nighttime respiration from eddy covariance measurements in moderately complex topography, Agr. Forest Meteorol., 148, 1174-1180, 2008.

Vitousek, P. M. and Sanford, R. L.: Nutrient cycling in moist tropical forest, Annu. Rev. Ecol. Syst., 17, 137-167, 1986.

von Randow, C., Manzi, A. O., Kruijt, B., de Oliveira, P. J., Zanchi, F. B., Silva, R. L., Hodnett, M. G., Gash, J. H. C., Elbers, J. A., Waterloo, M. J., Cardoso, F. L., and Kabat, P.: Comparative measurements and seasonal variations in energy and carbon exchange over forest and pasture in South West Amazonia, Theor. Appl. Climatol., 78, 5-26, 2004.
Wang, Y. P. and Leuning, R.: A two-leaf model for canopy conductance, photosynthesis and partitioning of available energy I: Model description and comparison with a multi-layered model, Ag. Forest Meteorol., 91, 89-111, 1998.

Wilson, K., Goldstein, A., Falge, E., Aubinet, M., Baldocchi, D., Berbigier, P., Bernhofer, C., Ceulemans, R., Dolman, H., Field, C., Grelle, A., Ibrom, A., Law, B. E., Kowalski, A., Meyers, T., Moncrieff, J., Monson, R., Oechel, W., Tenhunen, J., Valentini, R., and Verma, S.: Energy balance closure at FLUXNET sites, Agr. Forest Meteorol., 113, 223-243, 2002.

Wohlfahrt, G., Bahn, M., Haslwanter, A., Newesely, C., and Cernusca, A.: Estimation of daytime ecosystem respiration to determine gross primary production of a mountain meadow, Agr. Forest Meteorol., 130, 13-25, 2005.

Woodrow, I. E. and Berry, J. A.: Enzymatic regulation of photosynthetic $\mathrm{CO}_{2}$ fixation in C-3 plants, Annu. Rev. Plant Phys., 39, 533-594, 1988. 